\title{
THE REAL
}

\section{SIR RICHARD BURTON}

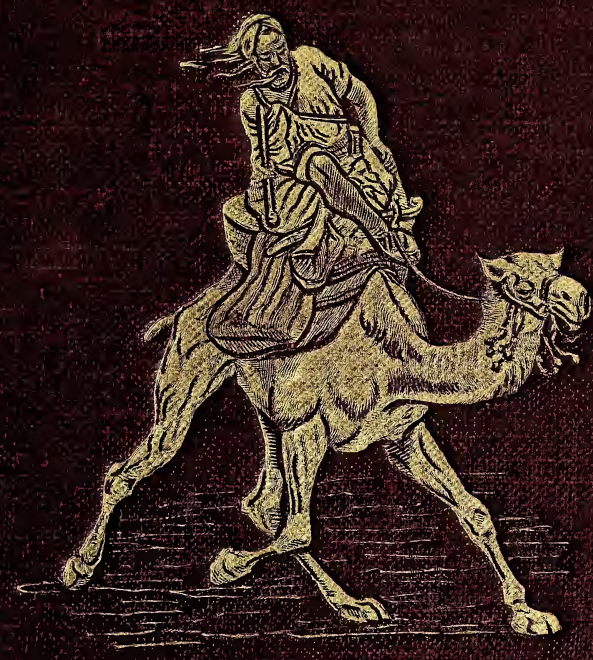




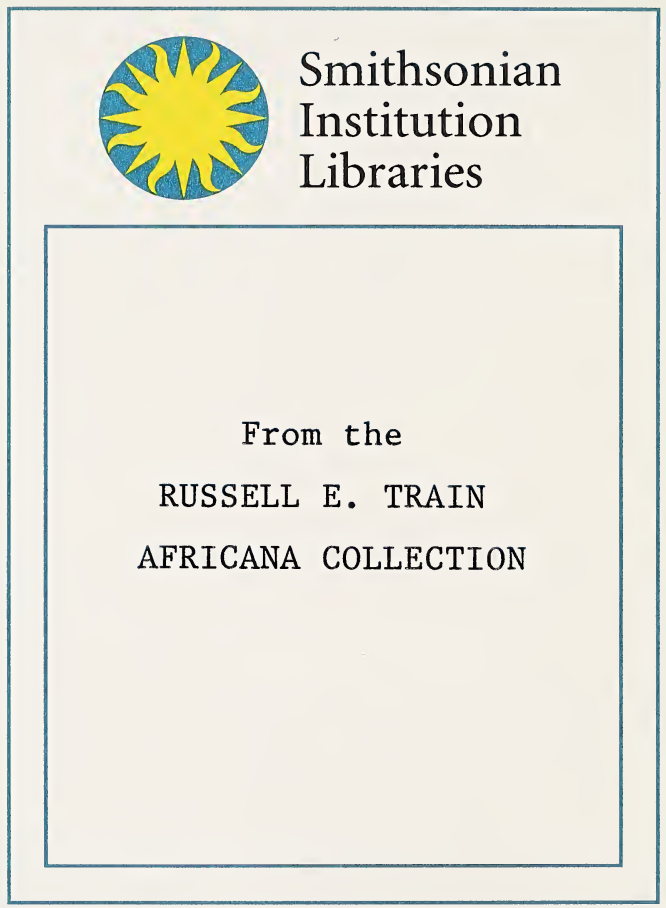






\section{THE REAL SIR RICHARD BURTON}



, w5

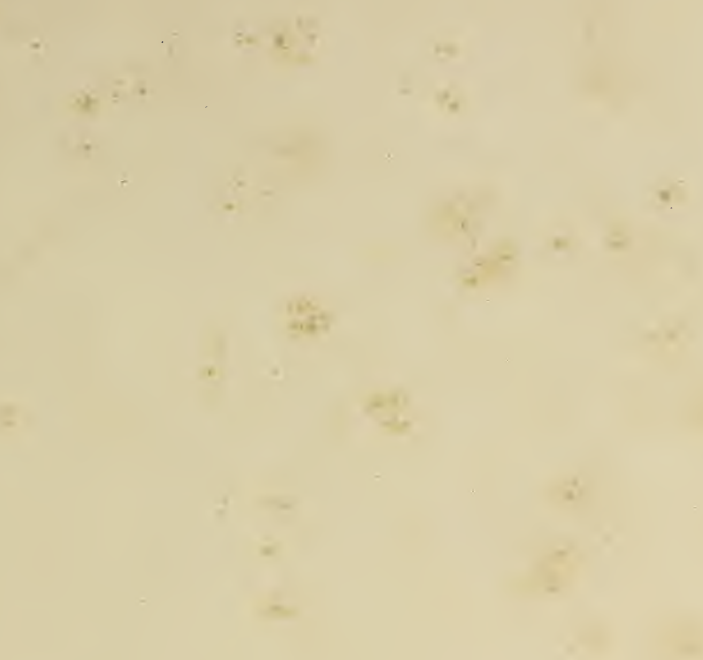




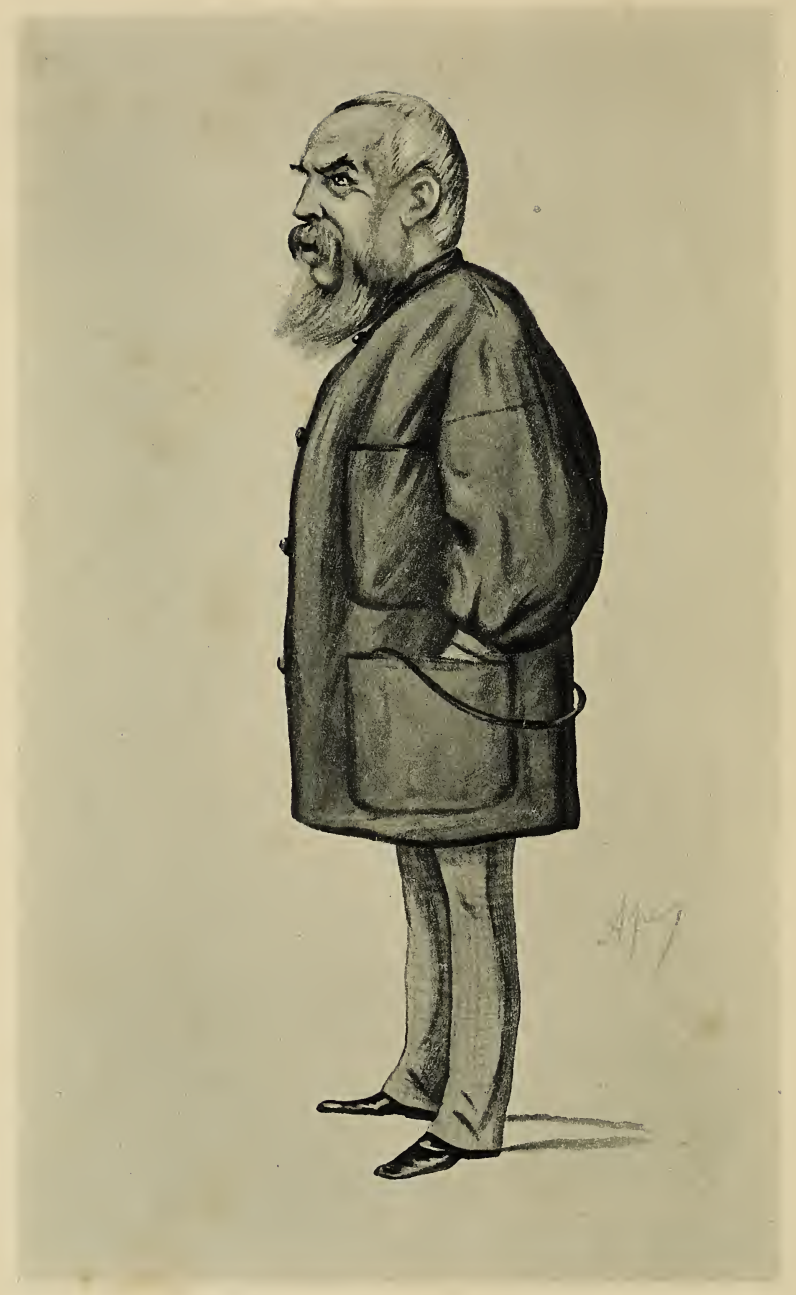

"IHE ARABIAN NIGHTS" 


\section{THE REAL}

\section{SIR RICHARD BURTON}

BY

\section{WALTER PHELPS DODGE}

OF THE MIDDLE TEMPLE, BARRISTER-AT-LAW, FELLOW OF THE ROYAL GEOGRAPHICAL SOCIETY, FELLOW OF THE AMERICAN GEOGRAPHICAL SOCIETY

Author of "Piers Gaveston" and "From Squire to Prince"

WITH A FRONTISPIECE

SECOND EDITION

LONDON

T. FISHER UNWIN

ADELPHI TERRACE

1907 
First Edition, June, 1907.

Second Edition, September, 1907.

[All rights reserved] 


\section{To}

THEODORE ROOSEVELT

PRESIDENT OF THE UNITED STATES

THIS RECORD OF A STRENUOUS LIFE 



\section{AUTHOR'S NOTE}

THIS book is intended to compete

1 with the various "Lives" of Burton. The first of these, "A Sketch of the Career of Richard F. Burton," by Richards, Wilson and Baddeley (London, 1886), is a rare but unimportant pamphlet. "Richard F. Burton," by Francis Hitchman (London, 1887), is an interesting account of the great explorer's travels.

Lady Burton's monumental "Life of Capt. Sir Richard F. Burton" (London, 1893), will always remain the standard work on the subject, in spite of its imperfections.

"The True Life of Capt. Sir R. F. Burton," by his niece, Miss Stisted (London, 1896), is useful, but is chiefly a depreciation of Lady Burton. 


\section{THE REAL SIR RICHARD BURTON}

"The Romance of Isabel, Lady Burton" (London, 1897), by W. H. Wilkins, is really a reply to Miss Stisted, and an attempt to exalt Lady Burton at the expense of her husband-an attempt she would have been the first to resent.

"The Life of Sir Richard Burton" (London, 1906), by Thomas Wright, is more of a Criticism than a Biography, and is a notebook, practically devoted to a discursive and abortive effort to prove that Burton did not rank as a translator with John Payne. Wright also absurdly states that Burton borrowed much of the material in his "Arabian Nights" from Payne. The fact that this accusation was first made years after Burton's death, and after the death of Lady Burton, Miss Stisted, and Mr. Wilkins, speaks volumes. The puerile charge disproves itself. As a matter of fact, Burton had collected his material for the "Nights" long before he met Payne, or before Payne had even thought of a translation. 
After reading these "Lives" one turns back with a sense of relief to Lady Burton's book. Her own words best describe the situation :-

"Loads of books will be written about him, and every one will be different; and though perhaps it will be an unseemly boast, I venture to feel sure that mine will be the truest one, for I have no interest to serve, no notoriety to gain, belong to no party, have nothing to sway me except the desire to let the world understand what it once possessed, what it has lost. With many it will mean 'I.' With me it means 'Him.'" *

To write another life of Burton, to challenge comparison with the different authors who have conscientiously-more or lessdevoted themselves to the task, would probably be for any one but Kipling a mistake. It needs the Chronicler of the Empire to

* "Life of Capt. Sir Richard F. Burton," by his Wife, Isabel Burton, Foreword, vol. i. p. xi. London: Chapman \& Hall, 1893. 
write of the greater Sons of the Empire. There is, however, room for a study of Burton's career, a fascinating career of romance and hard work, the career of one of the greatest of modern Britons.

There is a strong feeling that it is time to recognise the fame of the great explorer; and that it is but fair to place the name of Burton with Livingstone and Stanley, above those of smaller men who did lesser things.

The author wishes to acknowledge the courtesy of Vanity Fair (in allowing him to reproduce the famous cartoon of Burton); and to express his thanks for their kindness in answering questions to Mrs. Edward J. Burton, Col. St. George Burton, Mr. Frederick Burton, Mr. Mostyn Pryce, the Secretary of the Athenæum Club, Mr. Richard C. JACKson, Mr. W. F. KIRBY, and the Librarian of the Central Library at Camberwell. 


\section{CONTENTS}

II. HIS DESULTORY BOYHOOD . $\quad$. 21

III. HIS ARMY LIFE IN INDIA $\quad$. $\quad$. $\quad 39$

IV. HIS PILGRIMAGE TO MECCAH $\quad$. $\quad 57$

V. HIS EXPLORATION OF HARAR . $\quad$. $\quad 79$

VI. HIS CRIMEAN EXPERIENCE $\quad$ • $\quad$. 91

VII. HIS AFRICAN DISCOVERIES . . . . 101

VIII. HIS ROMANTIC MARRIAGE $\quad$. $\quad$. $\quad$. 117

IX. His CONSUlate AT FERNANDO PO $\quad . \quad 137$

x. His CONSUlate AT SANTOS $\quad$. $\quad 153$

xI. HIS CONSUlate at damascus . $\quad$. 169

XII. HIS CONSUlate AT TRIESTE $\quad$ - $\quad 189$

XIII. HIS LESSER TRAVELS • • . . 207

XIV. HIS DEATH $\quad$. $\quad$. $\quad$.

xV. ITE MISSA EST. $\quad . \quad \ldots \quad$. $\quad .235$ 



$$
\text { I }
$$

THE MAN 



\section{The Real Sir Richard Burton}

\section{I}

THE MAN

$\mathrm{O}^{\mathrm{N}}$ the 21st of October, 1890, the papers announced that the British Consul at Trieste had died on the previous day.

British Consuls had died at their posts before, but in the announcement of this death there was something that startled the nation. There was a shamed sense in the air that one of the greatest of English explorers-one of the most distinguished Orientalists of the age-had died in harness, a Consul at a third-rate seaport, after a long life of storm and stress, spent in the service of a country that was barely grateful.

What did this man do? He was on duty 


\section{THE REAL SIR RICHARD BURTON}

as a soldier for nineteen years in India in the service of the Honourable East India Company, and on Sir Charles Napier's staff. During this period he made the famous pilgrimage to Meccah and was the first white man to enter the city of Harar.

During the Crimean War he was Chief of Staff to General Beatson, and organised the Irregular Cavalry.

He was (as Richards well says) the pioneer of all other African travellers. His Lake Tanganyika unveiled the mystery of the sources of the Nile, and he was the discoverer and opener of the Lake Region of Central Africa.

He made countless journeys-dangerous in the extreme-in North, Central, and South America, in unexplored Syria, and in East, West, and Central Africa.

$\mathrm{He}$ spoke twenty-nine languages and dialects; he wrote over eighty books-all of them valuable to the world in many varied ways. He received the Gold Medal 
of the Royal Geographical Society and of the French Geographical Society.

He was a Maître d'Armes. He translated the "Lusiads" of Camoëns; while his translation of the "Arabian Nights" is recognised as the standard one.

He came from a fighting race; his people were army people, and he was proud to call himself a gentleman of Hertfordshire. There is no proof of any gipsy blood in the family, although the Burton clan enthusiastically claimed him as their own. The gipsy strain in Burton was mental, not physical, for his mind, although not wandering in the ordinary sense of the word, was a wandering mind.

Burton's ancestry was gentle on both sides. His father had left the Army at a comparatively early age, and seems to have developed peculiar views as to the education of his sons; and to this education, now lax, now strict, may be attributed the character that Burton developed in after- 


\section{THE REAL SIR RICHARD BURTON}

life--a character oddly marked by alternate streaks of strength and weakness. The real strength of Burton's mind is shown by the fact, that in spite of his desultory training he became one of the greatest linguists, one of the foremost Arabists of the day.

Why such an one died as British Consul at Trieste is an interesting problem. Burton had enemies, but what great man has escaped this blessing? They have become more active since the death of Lady Burton, who wielded a trenchant and mordant pen, and they still snarl at his reputation, growing greater year by year, but the baying of dogs at the moonlight does not lessen its light. 


\section{II}

\section{HIS DESULTORY BOYHOOD}



HIS DESULTORY BOYHOOD

$A \mathrm{~S}$ to the date and place of his birth, A Burton himself says: "I was born at 9.30 p.m. March 19th (Feast of St. Joseph in the Calendar), 1821, at Barham House, Herts, and suppose I was baptized in due course at the village church." *

He was christened Richard Francis.

Thomas Wright, however, in his "Life," states that Burton was born at Torquay on March 19, 1821.

Burton's niece, Miss Stisted, in her * "Life of Capt. Sir Richard F. Burton," by his Wife, Isabel Burton. London : Chapman and Hall, 1893, vol. i. chap. ii. p. 15. 


\section{THE REAL SIR RICHARD BURTON}

"True Life," says he was born at Barham House.

His father was Lieut.-Col. Joseph Netterville Burton; while his mother was Martha Baker. There were two other children in the familyMaria, who afterwards became Lady Stisted, and Edward, who died unmarried.

Colonel Burton was a great sufferer from asthma, and, in the vain hope of securing relief from his annoying complaint, roamed incessantly from place to place on the Continent, dragging his family about with him.

Under the influence of these constant changes it is not to be wondered at that the eldest son should have developed a habit of wandering about the world.

Tours was the first foreign objective point of the family. For this there were several reasons: the English colony was reputed select and exclusive; the educational facilities were famous and the air was dry. 
The Château de Beauséjour, the first home of the Burtons, soon became noted for its entertainments, and was known for famous wine-cellars. Colonel Burton spent nearly all his time at boar-hunting in the leafy recesses of the wood of Amboise, while Mrs. Burton was by nature, as well as by name, a Martha of old. From all accounts, the Burtons must have been charming people. "Nice to be able to feel proud of one's parents," Richard Burton used to say in after-life. His father appears to have been a handsome man; his mother, on the other hand, was rather plain.

Burton says himself he was like his mother, but Lady Burton indignantly negatives the statement in her "Life" (vol. i. p. 3 note): "This I deny. Richard was the handsomest and most attractive man I have ever seen."

A difference had been made to the financial position of the Burtons by the fact that 


\section{THE REAL SIR RICHARD BURTON}

Colonel Burton had been obliged to go on half pay by the Duke of Wellington for refusing to testify against Queen Caroline. $\mathrm{He}$ had been in control at Genoa when the Queen lived there, and her kindness to the officers and men had so impressed the elder Burton that he refused to appear against her. Richard Burton thoroughly approved of his father's course in this matter, although it compelled him to begin life as an East Indian cadet, while his cousins were in the Guards.

Richard Burton says of himself that he began Latin at three and Greek at four, but there is not recorded for him in these subjects the brilliant success that distinguishes the common or garden infant phenomenon.

At the age of six he was sent to a day school kept by a lame Irish schoolmaster with a vile temper. From his care Burton was transferred to that of a Scotch dominie, who caned his pupils regularly on the 
principle of an ounce of prevention. After this experience of the Celtic fringe, Burton showed a special aptitude for French, and a strong tendency towards the art of swordsmanship, an art on which he was later to become a recognised authority.

Burton says of himself at this school: "We boys became perfect devilets, and played every kind of trick, despite the rattan." It is to be doubted whether he then learned much, as his time seems to have been chiefly occupied in fighting his fellow-pupils, who were a mélange of all nations. In after-life he expressed himself strongly on the absurdity of bringing up English boys on the Continent.

About the time of the Revolution that placed the treacherous Louis Philippe upon the throne of his more deserving but unhappy cousin, Colonel Burton resolved to take his boys to England, realising that the experiment at Tours had hardly proved a success. The knowledge of French gained 
by the children during those early years was the only gain.

The heavy travelling carriage was brought out; and after an auction sale of household goods, Colonel and Mrs. Burton took their hopeful family back to London. It appears that Colonel Burton had intended to send his boys to Eton, but he abandoned this intention, to settle down in a roomy house at Richmond in Maids-of-Honour Row, where the boys were sent to a private school kept by one Delafosse (chaplain to the Duke of Cumberland), a sort of early English Squeers, whose teaching failed to supply the needed antidote to the Irish and Scotch "education" imbibed at Tours.

Here again Richard Burton distinguished himself by conflicts with the other boys. He was described by his sister at this time as "a thin, dark little boy, with small features and large black eyes." From a description of the food at this school one begins to believe in the doctrine of the 
survival of the fittest. For breakfast they had a mug of blue milk and a thick wedge of bread and butter; the dinner began with pudding and ended with meat; while the supper was breakfast over again. Midnight feasts were not to be wondered at, and there was little danger of over-eating. The constant fights and the poor food, however, agreed with Richard Burton. Even in those days he was manly and generous, although the miserable school system gave him little encouragement to be either. Another change, however, was at hand. Miss Stisted, in her "True Life," states that scarlet fever broke out in the school, while Burton himself calls it measles. At all events the school was dispersed, and Colonel Burton, who was thoroughly tired of the stuffiness of Richmond, decided to take his family to Blois, and forthwith engaged a tutor for his sons. The decision to return to the Continent, although welcomed by the family, was an unfortunate one. Colonel Burton did not 
realise that when his boys were ready to start in life they would look in vain for those friends whom they might have made in a great public school. If Richard Burton had gone to Eton or Rugby his career might have been richer in honours; richer in honour it could not be.

The tutor, one Du Prè, of Exeter College, Oxford, son of the Rector of Berkhampstead, was not a wise selection. $\mathrm{He}$ was awkward, ungenial, and with no sense of humour. For boys like Richard Burton and his brother a man of the world who was at the same time a Christian gentleman (a rare and ideal combination) was badly wanted. A bookish peering don in embryo was a useless addition to the family party.

At Blois the boys studied hard; while fencing claimed all their spare time. They were not popular lads, for their animal spirits were those of the fiercer beasts of the jungle.

A savage winter put Colonel Burton out 
of all conceit with Blois, and in the spring a move to Italy was decided on. The old family carriage took the party to Marseilles, whence they went by boat to Leghorn, thence to Pisa. After this they were constantly on the move. Siena, Perugia, Rome, and Florence saw them all in turn. At length they moved on to Naples, still under the direction of their tutor, whose negative qualities appear to have outshone his positive virtues. From Naples they went over to Sorrento.

The boys liked Sorrento, for there they did much as they pleased. Bacchus and Venus were the presiding deities of the place, whose altars were hardly the ones on which youth should lay its offering. After certain adventures had been brought to his notice, Colonel Burton seems to have realised this.

A short visit to Pau in 1836 involved both Richard Burton and his brother in a boyish romance with two sisters, a short-lived 


\section{THE REAL SIR RICHARD BURTON}

affair. Colonel Burton, as usual, soon tired of a new place; and after two winters at Pau the family returned to Italy, this time choosing Pisa. Here Richard Burton devoted himself again to fencing, having some idea of arranging a combination between the French and Italian schools. In afteryears he became a Maître d'Armes, and kept up the "noble art" until the end of his life.

The result of these studies was incorporated in the "Book of the Sword," published in 1880. No study in which Burton was ever engaged failed to provide him with some book on the subject, a book which usually took immediate place as an authority.

A summer at the Baths of Lucca proved conclusively to Colonel Burton that his boys had outgrown home authority, and that an immediate return to England, with a view to a University training, was imperative. 
Richard Burton went to Schinznach for a six weeks' cure, before joining his father and brother in London. At this time it appears that both boys were intended for the Church, but imagination fails in the task of picturing Richard Burton as a country curate.

Taken as a whole, the Continental education was a mistake. It was a bad preparation for college.

Richard Burton's career at Oxford was a curious one. Taken suddenly from life with a tutor on the Continent, he found the restraint of college life irksome in the extreme.

$\mathrm{He}$ was under twenty when he was entered at Trinity College in 1840. Unlike his fellows, he had no friends, and after his Italian training he had no great love for English weather, English cooking, English girls, or English ways.

Although he spoke French and Italian like a native, and had a knowledge of 
Bearnais, Provençale, and kindred dialects, he was woefully lacking in the classics, and his knowledge of the tribes so given to begetting in the old Testament was

an unknown quantity. His opinion of his rooms, which he called "a couple of frowsy dog-holes," shows his state of mind.

Driving tandem, lessons in fencing, long walks, talks with neighbouring gipsiesall these things amused him and filled his spare time. From his lecturers and tutors he learned little. He was totally unfitted for the narrow life of the Oxford of his day. Wishing to learn Arabic, he applied to the Regius Professor, who led a life of inglorious ease, but met with little encouragement, and resolved to acquire the language alone and unaided; with what success the world now knows.

Edward Burton at Cambridge was equally unhappy, and the brothers moaned with each other over their unhappy plight.

Richard Burton's chief Oxford friends 
were Thomas Hughes and Alfred Bates Richards, while he always cherished a deep affection for his tutor, the Rev. Thomas Short, a typical don, "fine old crusted vinegar of an early vintage."

With few intimate friends, without many resources, Burton threw himself into the study of Arabic and various Oriental dialects. During the Christmas holidays the brothers foregathered in London with some friends who were in the army, and it was at this time that both appear to have resolved to embrace a military career.

As Burton had learned the Continental pronunciation of Latin and Greek, he found it difficult to reform his vowel sounds, and this fact added to his troubles at Trinity.

During the long winter he studied, fought, loved, and fenced. It can be imagined with what glee the brothers welcomed the Long Vacation, which they spent in Wiesbaden and Heidelberg, where they studied 


\section{THE REAL SIR RICHARD BURTON}

the method of fighting between different corps of students. This method was barbarous and savage after the Italian school, and Richard Burton looked on it with contempt.

During this time the boys again made an appeal to their father for permission to enter the army, an appeal dismissed curtly by Colonel Burton, who still had visions of his sons as bishops to be.

When Richard Burton returned to Oxford he was desperate, and after some deliberation succeeded in getting himself rusticated by a carefully planned forbidden visit to the races. After his interview with the authorities, he left Oxford; driving tandem, in a blaze of undergraduate glory, happy in bidding farewell to an uncongenial almamater, where he had learned nothing but the Arabic he had taught himself.

The blame of his failure at Oxford rests with his father, not with him. To succeed at Oxford or Cambridge an English boy 
must go up from Eton or Harrow, not from desultory wanderings on the Continent with an apology for a tutor who is usually an unsuccessful author or a stickit minister. 



\section{III}

HIS ARMY LIFE IN INDIA 



\section{III}

HIS ARMY LIFE IN INDIA

COLONEL BURTON was annoyed by the course of his eldest son. His dreams of preferment in the Church for his boys were rudely shattered. Edward Burton lost no time in seizing the opportunity his brother's rustication had given him, and left Cambridge under somewhat similar circumstances, to become Surgeon-Major in the Army Medical Service at a later period. Richard Burton wisely gave his father space for reflection, and in due time reaped his reward, which took the form of a commission in the 37th Regiment, a gift from Lord Fitzroy Somerset, afterwards Lord Raglan. 


\section{THE REAL SIR RICHARD BURTON}

No time was lost in procuring the oldfashioned and cumbrous Indian outfit of the period, the only two items which proved of any service being a wig and a bull-terrier; the wig covering his head, shaven for coolth, and the terrier taking care of the savage rats on the ship.

On June 18, 1842, Richard Burton sailed in the good ship John Knox for Bombay, after being duly sworn in at the offices of John Company. The voyage around the Cape was a long and dreary affair.

Fortunately there were three Hindus on board, and he lost no time in polishing his Hindustani. Wherever Burton was, under whatever circumstances, he never lost an opportunity of improving his knowledge of any subject under discussion. Usually he was able to give information, but he always studied or talked with his mental pores open, ready to absorb any facts that might be going; throughout his life he preserved this attitude of mental receptivity. 
In due time the long voyage came to an end, and Burton arrived at Bombay on October 28, 1842.

In those days the casual Court of Directors made poor provision for the cadets under their care. Creature comforts were far to seek. There was little society, and the newcomer had to choose between sport and a varied assortment of native vices to fill up his spare time.

It was characteristic of Burton that he struck out a line for himself and plunged at once into study of Indian dialects.

An old Parsee was engaged as master, and never was teacher so hard worked by an eager pupil. The tutor ever after spoke of Burton as one who could learn a language running.

A short illness caused a removal to the local sanatorium, a collection of bungalows, little better than the so-called British hotel, where, however, he rapidly regained his health, and after six weeks was ordered to the 18th Native Infantry at Baroda. 
A two weeks' voyage in a pattymar, a native craft carrying huge lateen sails, together with a collection of Goanese servants, brought Burton to his landing-place in the Bay of Cambay.

A four days' march proved as enjoyable as the voyage.

Burton galloped ahead of his company and scrutinised every inch of the country with an eye for the strange and unknown. When he reached Baroda in the pink of condition, keen for his new duties, he soon found that he had all the spare time that he wanted to devote to languages.

Parade was at dawn and lasted until after sunrise. The whole day before dinner at mess was left for study. So fierce was Burton's ardour, both in mastering Arabic and Hindustani that he studied twelve hours a day, and his two masters could hardly keep. up with him.

Wright speaks of an irregular union entered into by Burton at this time, but quotes no 
authority. Burton throughout his life was a moral man. Whether his morality was mental or temperamental matters little. The fact remains.

During his stay in India he never wasted a minute. He was not content with knowledge of Eastern languages, he studied Eastern customs, Eastern people, and Eastern religions; although his experiences were sometimes unpleasant, he was thorough.

On May 5, 1843, Burton having obtained leave, passed, first of twelve, in Hindustani, at Bombay. After his disastrous Oxford experience, this success only whetted his ambition, and on his return to Baroda, during the rainy season, he worked hard at the Gajurati language. He also took lessons in Sanscrit.

Such progress did he make not only in the language, but in knowledge of the customs of the country, that his teacher, one Him Chand, a Nagar Brahmin, allowed him officially to wear the Brahminical thread of the twice-born-the Janeo. 


\section{THE REAL SIR RICHARD BURTON}

In those days ale was king in India. The brandy pawnee of an earlier generation had given place to malt liquor. Moderate men, says Burton, drank two bottles a day; others went through a round dozen. Burton himself stuck to two daily glasses of port, an excellent febrifuge.

The days of the "peg" had not then arrived. Whiskey-and-soda, the universal drink of the India of to-day, was in Burton's time non-existent.

An examination in Gajurati at Bombay in August, 1843, was successful, and an appointment as Regimental Interpreter quickly followed, with a small language allowance.

At length the regiment was ordered to Sind, and Karáchi became the next abiding place of the ambitious subaltern.

Two books resulted from this change of appointment-"Scinde, or the Unhappy Valley," 1851, and "Sind Revisited," 1877, both standard works on the country. Burton's knowledge of detail was encyclo- 
paëdic. He appears to draw a fine-meshed net through all the customs of a country, and to then embody the essence of his trove in well-chosen words. His pen pictures give one a better idea of the country than many photographs. A favourite tale of his was the clever despatch sent by Napier when he had conquered Sind: "Peccavi."

In Burton's character there was a total absence of petty jealousy: he could always enter into the success of another even when he himself had been passed over.

In October, 1844, he successfully passed in Màráthi, a language he had mastered at the wretched village of Ghára, during one hot season when the temperature averaged $118^{\circ}$.

Through the influence of his friend, Colonel Walter Scott, Burton was gazetted assistant to the Canal Department of the Survey in Sind. This change from dull, regimental routine was very welcome, while he had a particular joy in finding that he alone could translate some important Italian works on 


\section{THE REAL SIR RICHARD BURTON}

hydrodynamics. He says of himself, at this time, "After the first year, when I had Persian at my finger-ends, sufficient Arabic to read well and converse fluently, and a superficial knowledge of that dialect of Punjaubee which is spoken in the wilder parts of the province, I began the systematic study of the Indian people." This systematic study was responsible for yet another work- "Falconry in the Valley of the Indus," 1852. At this time Burton began his observation of the people in the most practical way, by dressing as one of them, living with them, and passing as one of themselves. His command of language and dialect, his Eastern look-he was dark and tall-his perfect coolness and dignity, enabled him to see sights that are seldom to be seen, and to hear things not meant for the ear of the Sahib-log. Disguised as Mirza Ali Abdullah of Bushiri, with his face, neck, and arms stained, a long beard ageing his too youthful face, he stepped down into the native crowd and disappeared. 
Lady Burton seemed to think that Burton was the original of Kipling's " Strickland," and it may well be true. At this time Burton earned the sobriquet of "The White Nigger," as when he returned from his frequent pilgrimages he spent his time with Khan Bahádur Mirza Ali Akbar, who lived with his friend, Mirza Dáud, a famous Persian scholar, outside the camp. Here Burton engaged a Persian Munshi, whom he got to open some small shops in the bazaar at Karáchi, where Burton would sit for hours stolidly listening to the gossip of the people.

This information, together with notes obtained on an expedition to investigate certain customs of the natives, he afterwards incorporated in his "Terminal Essay" to his Arabian Nights, which he called "The Thousand Nights and a Night."

Even in these days Burton made enemies by the epigrams and lampoons he constantly launched at those unfortunate acquaintances who had annoyed him. 


\section{THE REAL SIR RICHARD BURTON}

At this time he states that "I left off sitting under the garrison chaplain and transferred myself to the Catholic chapel of the chocolate-coloured Goanese priest."* This statement is interesting in view of Miss Stisted's attack on Lady Burton for having had Extreme Unction administered to her husband as he lay in articulo mortis in Trieste.

In November, 1845, Burton went for a long tour with his friend Colonel Scott, a nephew of the Wizard of the North, who was delighted to find a man who would talk Froissart with him. Both Miss Stisted in her "True Life" and Wright in his "Life" dignify with mention an apocryphal and legendary passion for some mysterious Persian maiden whose memory was said to haunt Burton. Statements of this sort are easy to make, but no authority is quoted. Burton was the least sentimental of men, and the one great passion of his life was his love, the love of a strong man armed, for his wife.

$$
\text { * Lady Burton's “Life," vol. i. p. } 123 .
$$


When trouble with the Sikhs began there was no holding the fiery young soldier back. Despite all Scott's remonstrances, Burton persuaded him to accept his resignation, and rushed off, as he hoped, to active service. The war, however, was over in a few weeks, and Burton had no chance of distinguishing himself. Returning to the old regimental quarters, he went back to his studies, and amused himself again by lampooning his fellow-officers. One verse on his colonel annoyed that worthy to such an extent that he made Burton's life a burden to him:-

"Here lies the body of Colonel Corsellis; The rest of the fellow, I fancy, in hell is."

On the other hand, he had several good friends, notably Dr. Steinhuser, who afterwards, Burton states himself, "became my collaborateur in the "Thousand Nights and a Night." ", *

The summer of 1846 was unhealthy, and * Lady Burton's " Life," vol. i. p. 148. 
Burton was in "sick quarters" from July to September, when he obtained two years' leave of absence in the Neilgherries. On February 20, 1847, he sailed for Goa, where he lost no time in getting material for his book on "Goa and the Blue Mountains," 1851. A visit to Ootacamund seems to have caused an attack of rheumatic ophthalmia, which lasted off and on for about two years. In the intervals of treatment Burton, as usual, wasting no time, studied Telugu and Todu, with Arabic and Persian, and took up ethnology for a change of subject. In September, 1847, he went to Calicut to study the "Lusiads" of Camoëns on the spot, and returned to Bombay in a monsoon.

On October 15th he passed in Persian, first of thirty, and was glad to receive a honorarium of Rs. 1,000 from the mildewed Court of Directors.

Upon his return to the headquarters of the Survey, Burton began to work at the study of Sindi, and to investigate Moslem Divinity; 
learned more than a quarter of the Korán by heart, and became well up in all the ceremonial usages of Moslem prayer. A study of Sufi-ism, the Mysticism of Al-Islam, was a source of keen enjoyment. When tired with this fairly hard régime, he "refreshed" his mind with a course of Sikh religion and literature!

At this time he was solemnly initiated in the presence of the swinging Granth, and became a Master-Sufi. Even at this early period he seems to have planned for the great pilgrimage to Meccah, and lost no opportunity of preparing for what he knew to be an almost impossible task.

It is interesting to note that he found, in carefully undergoing the Chillá, or quarantine of fasting, that his brain became over-excited.

That he was not a popular man in his regiment it would be idle to deny. There was a certain jealousy among his brother officers, who could not understand his preference for serious studies over their more brutal sports. 
As Burton had more trouble with his sight, he worked his mind harder. He studied, fourteen hours a day, Mantih or Eastern logic and Arabic. He now began to regret the time wasted at Oxford over such esoteric authors as Zadkiel, Old Moore, and Cornelius Agrippa.

In assuming native disguise Burton had preferred to pass as a half Arab, half Iranian from the shores of the Persian Gulf. This character allowed for fluency in many dialects but required perfection in none. Added to this, he had a knowledge of the Shiah religious customs common in Persia, and a stock of tales of wonderful variety with which he could regale any one with whom he came in contact, from a Sais to a Ranee.

Burton's friends often tried to induce him to write a book of his adventures, when, in disguise, he had wandered over the face of the land. What salt tales were there! But somehow the book was never written, and a classic was lost to the world.

No one was ever in touch with the native 
races of India as Burton was. He managed to think like an Eastern, and got to the back of the Oriental mind, a thing the average English or American officer is stodgily incapable of doing.

If ever the East and West have met, it was in the mind of Richard Burton. Had his career gone on in its naturally appointed course, he would have made such a Viceroy of India as has not yet been seen.

Burton's study of different religions appears to have induced a cynical state of mind on the subject of religion generally. This phase, however, was not permanent, and long before he died he grew more orthodox. That he greatly admired the Koràn there is no doubt; that he preferred it to the Bible there is no proof. There is, however, proof that, whatever he was, he was never an atheist.

The spring of 1848 brought the chance of another expedition. Colonel Scott was ordered to prepare for active service, and 


\section{THE REAL SIR RICHARD BURTON}

Burton eagerly applied for permission to accompany the troops as interpreter.

Unfortunately some of his epigrams had rankled in official breasts, and his mastery of many languages did not secure him the post, which was given to some young ass with influence and no knowledge.

Burton's worry and annoyance over this rebuff was so great that his eye trouble came back with renewed violence, and he was hardly able to get as far as Bombay on his way to England. There his constitution gave way, and he was carried, a living skeleton, aboard the sixty-year-old brig Eliza. In his own eyes his Indian career was a failure. As a matter of fact, it was a success in the way of training for the great events to follow. 


\section{IV}

HIS PILGRIMAGE TO MECCAH 



\section{IV}

HIS PILGRIMAGE TO MECCAH

$T^{H E}$ voyage quite restored Burton's

1 health; he needed the long rest, and

his eyes benefited as his general condition improved. As soon as he landed he went to see his relatives, made a flying trip to Oxford with some vague idea of taking his degree, and then hastened to Pisa to visit his parents. He luxuriated in the quiet and peace of the city by the Arno, finally regained perfect health, and accompanied his father and mother to England to spend the greater part of the following year between Leamington and Dover.

In 1850 Burton went with his family to 
Boulogne, where he busied himself in perfecting his fencing and in bringing out various books on India and a valuable treatise entitled "A Complete System of Bayonet Exercise," a book which met with little or no success at the moment, but which has long been used as a guide at the Horse Guards.

By this time Burton had begun to be regarded as a coming man; his books attracted some attention and his future success seemed assured.

Here at Boulogne began the great romance of his life. Here he met the charming girl he was afterwards to marry, one who proved the ideal wife for this strange character, out of place in any age but the "Cinquecento."

Lady Burton describes their first meeting. "One day when we were on the ramparts the vision of my awakening brain came towards us. He was five feet eleven inches in height, very broad, thin and muscular; he had very dark hair, black clearly defined sagacious eyebrows, a brown weather-beaten complexion, 
straight Arab features, a determined-looking mouth and chin, nearly covered by an enormous black moustache. .. He had a fierce, proud, melancholy expression, and when he smiled he smiled as though it hurt him, and looked with impatient contempt at things generally."

This was evidently the "damn-it-all" expression that irritated many consequential acquaintances in after-days. He was easily bored and never cared to conceal his boredom, having a special dislike for elderly women on the fringe of society and for argumentative and ignorant young men. For these two classes he always declared there was a special hell with an extra brand of coal.

When he met his future wife for the first time on the ramparts he started a little and stared. She turned to her sister and said, "That man will marry me." The next day he met the girls again, and, picking up a bit of chalk, wrote on the wall, "May I speak to 
you ?" The future Lady Burton seized the chalk which Burton had left and wrote in her turn, "No; mother will be angry." Unfortunately her mother saw these notes in chalk, and the sisters, who were busy over their studies, were more strictly treated than before.

The charming girl was a Miss Isabel Arundell, daughter of Henry Raymond Arundell, a nephew of the ninth Lord Arundell of Wardour. Her mother was a sister of the first Lord Gerard.

Several days later a cousin of the Arundells introduced Burton to his inamorata, and from that day on their mutual attraction never wavered in the smallest degree. They had each met their affinity.

Years before Isabel Arundell had been told by an old gipsy, Hagar Burton, that the name of her tribe would exercise a great influence over her life. When she heard the name of the man whom she so much admired she was naturally startled. 
At this time Burton played a practical joke that has been often quoted against him, particularly by those numerous critics whose lack of a sense of humour is only equalled by their malevolence. The good taste of the joke may be questioned, but not the fact that it was a joke. Before he had met Miss Arundell, Burton had begun a chaffing friendship with a showy English girl who had an impossible mother - the sort of people who " have an egg to their tea" at home and dine lavishly abroad. Upon receipt of a note from this stout but worthy matron, Burton went to call on her, accompanied by his friend Dr. Steinhuser, a man of impassive face and humourous turn of mind. After a laboured conversation, the woman finally said, with an attempt at dignity, "I sent for you, Captain Burton, to inquire your intentions with regard to my daughter." " Strictly dishonourable, madam," replied Burton, as he bowed himself out with his impassive friend. Needless to say he heard no more of these people. 
Miss Arundell and Burton soon met again at a dance given by some cousins, and the romantic girl kept for years the sash and gloves he had touched that evening. They both believed they were the divided halves of one soul, and no person could have kept them apart for long, although obstacles that seemed insurmountable lay between them and the goal of their hopes. In the first place the Arundells were old English Catholics, the strictest of the strict, while the Burtons were Low Church people. Both families objected to an engagement, while Burton could barely keep himself, let alone a wife and a possible family. In this case, however, as in many others, the more difficult the course the truer the love. No woman could have been more suited to Richard Burton than was Isabel Arundell. To a womanly devotion for her lover she added the keen friendship of a man. She lost no opportunity of breaking a lance on Burton's behalf, and it is a significant fact that all the attacks on Burton and 
his wife were made after Lady Burton's death. What acrid fun she would have made of Miss Stisted's "True Life " and Wright's "Life!" That biting pen of hers would have run to a reply that had left her opponents speechless, but she died too soon.

At this time Burton's long maturing plans for an expedition to Meccah and Al Madinah rapidly took shape.

Such an adventure seemed incredible to all who heard of the idea. To the natural dangers of the desert was added the risk of being found out by the fanatical Moslems, who would give short shrift to any dog of a Christian. Among other preparations for the journey the enthusiastic soldier learned carpentering and mastered the art of shoeing a horse.

With some difficulty Burton, after offering his services to the Royal Geographical Society, obtained a furlough of twelve months that "he might pursue his Arabic studies in lands where the language is best 
learned," a diplomatic way of intimating that the Bombay authorities washed their hands with the soap of irresponsibility.

Burton's original idea had been much more ambitious than the pilgrimage to the Holy Cities. He had planned to spend three years in Arabia, crossing the unknown peninsula in a straight line either from $\mathrm{Al}$ Madinah to Maskat or from Meccah to Makallah, on the shores of the Indian Ocean. However, for some reason the fossils in the Court of Directors refused Burton's application for three years' leave, remarking that the suggested exploration was too dangerous. On this account Burton had to content himself with one year's leave and a pilgrimage to the birthplace and tomb of the Prophet. Here he reaped the reward of his prolonged and arduous Oriental studies. It is not too much to say that Richard Burton was the only man, at that time, who could have successfully made the pilgrimage, disguised as one of the Faithful. 
He made his final arrangements in London, spending much of the time with his mother and sister at Bath. He had decided to assume his disguise at once upon leaving London; and early in April of 1853 he left Southampton in the P. and O. steamer Bengal as Mirza Abdullah of Bushiri, with his friend Captain Grindlay, of Bombay fame. Tender memories of the young girl at Boulogne accompanied him, and Isabel Arundell, even in those days, was seldom absent from his thoughts, as he was ever present in hers.

The time of the voyage passed slowly. It was spent by Burton in diligently practising the many ceremonial customs of the Moslems in drinking, bathing, and eating. Any departure from these foundation-stones of belief would have been bitterly resented, and dangerous in the extreme. So successful was Burton, that upon his arrival in Egypt he was blessed as a True Believer. At Alexandria he spent a month in order to perfect him- 
self in all minor details. He said himself in after-years that he actually thought as a Moslem, and for the time being really regarded all Europeans as infidel dogs.

This getting inside the character of the disguise of the moment was the secret of his success, for he was never satisfied with anything short of perfection. During this quiet month Burton matured his plans and studied elementary surgery. $\mathrm{He}$ had a strong leaning in this direction, and might have made his mark in the College of Surgeons.

At the end of the month he procured a certificate from his Consul describing him as a British Indian, and at once took a Nile boat for Cairo. He travelled in light order, for he never studied comfort while on the march. A bag of dates, bedding, pen and ink-horn, a few necessary changes of clothes, with the simplest toilet articles, completed his equipment.

It took him three days and nights to 
get to Cairo in the wretched tub called the Little Asthmatic, while the burning sun of the desert glared down on the unfortunate pilgrims squatting on the unsound deck.

During the voyage Burton sat alone, telling the beads of his big rosary continuously. For refreshment he drank the filthy water of the river and munched bread and garlic as to the manner born. $\mathrm{He}$ had chosen to be a dervish, for the dervish is the chartered libertine of the desert, and may do and say things that no other pilgrim would dare.

Added to this, Burton knew enough medicine to pose as a Hakim, or doctor, a pose that was of immense advantage to him in getting nearer the people in general. Burton on the whole was much better equipped for his task than the Swiss traveller Burckhardt, who had scrambled into the Holy City and out again, animated more by a fear for his own 
life than by the spirit of scientific exploration that moved Burton.

An Alexandrian merchant, who became a fast friend of the traveller, counselled him to adopt the character of a Pathan or Afghan rather than that of a dervish or a Persian; but Burton always listened to advice with an impassive face. He rarely or never followed it.

There was much trouble in finding a reliable servant to look after the luggage; finally, however, he obtained an inoffensive lad from Surat, Nur by name, and a boy from Meccah who seems to have been a curious combination of the London streetboy and the True Believer. With all his faults this latter boy was useful, and took particular delight in naming Burton to his friends by the Arab travestation of his Indian nickname, "Ruffian Dick," which he had learned in some mysterious way.

Burton was glad to leave Cairo and start on the long and weary pilgrimage. With 
his usual care for detail, he explored every bit of the town and actually achieved some success as a physician among the common people.

From the Meccah boy was bought the pilgrim garment and the shroud (kafan) which the pious Moslem takes on such occasions. Supplies were laid in for the long ride over the desert to $\mathrm{Suez}$ and for the further voyage. These supplies consisted of tea, coffee, rice, and dates, with four water skins.

Not wishing to carry a large sum of money, Burton contented himself with the sum of $£ 80$ in gold and silver.

The story of this wonderful expedition is set out in the deeply interesting "Pilgrimage to Meccah and Al Madinah," published in 1855. It well repays perusal.

At Suez Burton was fortunate enough to meet some merchants on their way back to Al Madinah. They were all stopping at the same inn or "wakalah," and foregathered 
in great content, as they appeared to have similar tastes. Among these men was one Shaykh Hamid, who afterwards acted as Burton's host.

A long delay at Suez followed the eightyfour mile ride from Cairo. There were endless formalities and much red tape. Finally the mass of pilgrims sailed on the small boat Golden Wire, a sambuk with narrow bows. Her extreme passenger limit was sixty, but she had nearly a hundred on board. On this boat, crowded to excess, with hourly fights among the pilgrims to enliven the voyage, Burton spent twelve most miserable days. The distance was only about six hundred miles, but as the boat anchored at night the progress made was slow.

As usual, Burton utilised every moment of his time in studying accent, intonation, and ceremonial customs. Twelve days of such close and unpleasant personal contact was of great service to him. At Yambu 
there was opportunity for rest, which after his late experience he regarded as luxury. Here the last preparations were made. $\mathrm{He}$ hired two camels and bought a litter or Shugduf, as well as large stores of provisions.

At this time he dressed himself as an Arab, the costume in which he is most familiar to readers of his works.

The caravan he had arranged to join hired an escort of irregular cavalry, which did not prove to be of much use.

From Yambu Burton soon reached the "Red Village" El Hamra, where he waited for the caravan from Meccah. After four hours' delay he started with his new companions, and soon appreciated the advantage of their presence, as that same evening they were attacked by predatory "Bedawi," who captured twelve men and several camels.

On the morning of July 25th every one suddenly began to hurry, and all talk was stilled, when all at once, emerging from a 
cavernous pass, a full view of the beautiful city of $\mathrm{Al}$ Madinah met their eyes. At the sight every one indulged in the most poetical expressions. "Oh, Allah, this is the sanctuary of thy apostle; make it to us a protection from hell fire," \&c., \&c. For the moment Burton was as enthusiastic as the Moslems; then he hurriedly and surreptitiously made a rough sketch of the distant town.

At Al Madinah Burton spent a quiet, peaceful time with Shaykh Hamid, who treated him as one of the family. His time, of course, was much taken up in visits to the tomb of the Prophet, and the countless shrines in the town; in ceremonies to be performed, and in the usual prayers, five times a day.

In spite of his fatigue, he visited the Prophet's tomb on his first afternoon, and was much disappointed at the mean and tawdry appearance of a place so sacred to the whole Moslem world. 
Here Burton was known as the "Father of Mustachios," so long and splendid was his lip thatch.

Shaykh Hamid was desolate at the prospect of losing his guest, particularly as the caravan to Meccah was to travel over the Royal Road, or Darb El Sultani, where no water was to be had for three days.

Burton at this time became very fond of singing the favourite desert song of the Bedawi-the "Song of Maysinah":-

"Oh, take these purple robes away, Give back my cloak of camel's hair; And bear me from this tow'ring pile To where the black tents flap i' the air."

Burton's departure for Meccah on Sep tember 1st was greeted with tears, so popular had he made himself in Al Madinah during his six weeks' stay.

The caravan journey to Meccah was uneventful. No suspicion as to Burton's nationality was ever aroused, and to the 


\section{THE REAL SIR RICHARD BURTON}

end he continued to be regarded as a True Believer and one of the Faithful. After ten days and nights they arrived at Meccah, where Burton became the guest of the mother of his boy Mahommed.

Forty-seven miles before reaching Meccah the pilgrims had been obliged to stop to pass through the hands of a barber and to put on ceremonial attire.

At Meccah Burton at once again performed all the necessary formalities, including the circumambulation of the Haram. Early the next day he went to the Holy Well, Zem-Zem, and to the Ka'abah, in which is the well-known black stone. This stone he managed to kiss after elbowing his way through the immense crowd. While kissing it, he scrutinised it carefully, and decided it was an aerolite.

The picture of this one solitary Christian among these fanatical Moslems is an interesting one. A little fault, a mistake in some small ceremony, would have meant a pecu- 
liarly unpleasant death at the hands of bloodthirsty fanatics.

The man, in conceiving and carrying out such an expedition, is worthy of the greatest admiration.

As to Burton's Arabic, Abd-el-Kadir told Lady Burton long after, that there were only two men in Damascus, Captain Burton and Lady Ellenborough's Arab husband, Shaykh Mijwal-el-Mezráb, whose Arabic was worth listening to.

From Meccah Burton came safely to Jeddah with few adventures; and never was the sight of British Consulate more welcome.

His funds were nearly exhausted, and he lost no time in getting the Consul to change a draft for him.

The pilgrimage was over. Burton had finished the first of his great exploits, and when his book was published his name rang through the world. There were not wanting those of the missionary caste to decry his work-indeed, throughout his career he was 


\section{THE REAL SIR RICHARD BURTON}

exposed to annoyance from the Pecksniff type of missionary-but that he had done something never done before there was no one to deny.

He says of this expedition :-

"I have been exposed to perils, and I have escaped from them ... and my heart is moved with emotions of gratitude that I have been permitted to effect the objects I had in view." *

* Lady Burton's "Life," vol. i. p. 179. 
HIS EXPLORATION OF HARAR 



\section{V}

HIS EXPLORATION OF HARAR

DRING the long pilgrimage to the Holy Cities Isabel Arundell had not forgotten Richard Burton, and it was for his sake that she refused several brilliant matches in the exclusive set which surrounded her people in London. She read and re-read those of his books in print, and lost no opportunity to express her admiration of the gallant explorer.

Burton, meanwhile, was resting in Cairo and trying to think again as an Englishman. Finally the end of his leave compelled him to return to Bombay and to his regiment-a wholesome change, for at this time 
he needed a taste of the dull routine of regimental life in time of peace. It is to be regretted that he did not return to England to reap the reward of his daring, while his name was on the lips of men.

Often during his career the cup of the wine of full success was ready to be drained, but through his failure to be on the spot, the wine when quaffed was found to be flat and stale. At this time Isabel Arundell wrote in her diary :-

"Richard has just come back with flying colours from Meccah; but instead of coming home he has gone to Bombay to rejoin his regiment. I glory in his glory. God be thanked." *

A wild crop of absurd legends grew up in time about Burton's pilgrimage. These legends, which withered and died like weeds in the sun of publicity, were due to Burton's foolish boyish habit of trying to shock people by making himself out to be a monster. * "Romance of Isabel Lady Burton" London, 1897. 
About this time he became known to his friends as "The Haji."

On his way back from Meccah Burton had composed what has been called the most exquisite gem of Oriental literature ever written. He called it "Kasîdah," or "Lay of the Higher Law."

It is a poem of wonderful strength, on the destiny of human beings, pantheistic in its entirety, and full of Oriental learning. It was written in 1853, long before Burton had seen the Rubaiyát of Omar Khayyám.

Burton's verse has been called strained and turgid, but no one can apply either of these epithets to the Kasîdah. It opens :-

"The hour is nigh, the waning moon walks forth to rule the later night,

Crowned with the sparkle of a star, and throned on orb of ashen light."

His time with his regiment was short, for further dreams of exploration and adventure filled his head. No journey attracted him 
unless it had some hint of danger, no travel appealed to him without its own peculiar risk. He was soon to have full measure of both.

The Eastern Horn of Africa had long been awaiting exploration, and Burton conceived the idea of penetrating to the mysterious city of Harar in Somaliland, a task of no small magnitude. The Honourable East India Company knew that Berberah, the port of Somaliland, was the safest and most useful harbour on the western side of the Indian Ocean, and had long wished to know more about this strange land. They accordingly gave Burton leave to travel as a private personage; that is, he had no official mission, but received the usual "leave pay."

This expedition of Burton's was one of his most useful and most dangerous explorations. It is not so well-known as his other travels, for he was absent only four months, and his pilgrimage to Meccah naturally 
damped its importance. It proved, however, in the future, of great use to many countries.

Again Burton was compelled to modify his original plan, as the authorities considered it too ambitious. $\mathrm{He}$ applied for four assistants-Lieutenant Speke, with whom he later had an unhappy experience, Lieutenant Stroyan, and Lieutenant Herne. Speke and Herne belonged to the Bombay Army, while Stroyan was attached to the so-called Indian Navy.

Sir James Outram, the Resident at Aden, compelled Burton to change his route-an ill-advised proceeding. Finally it was arranged that Herne should go to Berberah, where Stroyan was to join him later, while Speke was to land at Bunder Guray to trace the watersheds and buy camels.

Burton himself resolved to enter Harar in the disguise of an Arab merchant, the most dangerous task of all. No white man had ever entered Harar. The attempt had been 
made by numerous travellers, but none had succeeded.

Burton, through his mastery of Arabic and the fact that he had performed the Hajj, was more fortunate. After a short stay at Aden, where he foregathered with his old friend Dr. Steinhuser, his only collaborator in his wonderful edition of "The Arabian Nights," Burton, on the 29th of October, 1854, disguised as Haji Abdullah, an Arab merchant, sailed in a small ship for Zayla.

$\mathrm{He}$ took with him two members of the Aden police and the local Moslem priest, a man of wonderful resource in rascality and of ready wit.

At Zayla, after a quiet voyage, they were met by the annoying news that there was trouble between the Governor of Zayla and the Amir of Harar. This situation required much thought on Burton's part, and he settled down at Zayla, in the philosophic patience of a True Believer, to wait upon events. To 
start on a journey of over a hundred and sixty miles through a country certainly strange, and probably hostile, was a serious undertaking and one requiring much care and forethought.

During his enforced leisure Burton often entertained the habitués of his favourite café with tales from the "Nights"-tales which, when translated as he alone could translate them, many years later, fixed his place unalterably as an Oriental scholar, and replaced all other versions of the "Nights."

Burton's account of this expedition is to be found in his extremely interesting "First Footsteps in East Africa," 1856.

After many delays, the expedition finally left Harar on November 27, 1854. It was a strange company. First came the Abban, the protector of the caravan, a petty Eesa chief, clothed in a sheet, carrying a battered shield and a heavy spear. Then followed the two fat cooks, buxom women of uncertain age, who acted as additional beasts of burden 
when required. Five camels stalked after, heavily laden, and close by, closing up the rear, came Burton's three Somali servants in fresh and gaudy attire. Last of all came the Haji, soberly pacing along on a white mule, solemnly telling his beads - a picture of Moslem dignity and urbanity. The ranting, roaring Burton of old women's tea parties had no real foundation in fact, for Burton's dignity never failed him.

The journey that followed was a long and dangerous one, full of exciting incidents and rich in acquired knowledge of all sorts. Through pastoral scenes, over boggy plains, up high mountains, often having brushes with wandering Arabs, the caravan went slowly but steadily on. On December 20th Burton had a violent attack of fever at a kraal; he recovered, but suffered a relapse at the end of December, when he was again seized by sudden illness, and lay for fortyeight hours in an almost comatose condition. The natives treated him with the greatest 
kindness. He soon recovered, and pushed on to Harar, where he spent ten days.

$\mathrm{He}$ was received with some distrust, but soon satisfied his sullen hosts that he cherished no ulterior motives. He made copious notes, sketches, and diagrams, fraternised with men of all nationalities, haunted the bazaars, and as usual lived every minute of his ten days-a wonderful ten days for the first white man in Harar.

The return journey was taken, by way of a change, direct to Berberah, and found dangerous in the extreme, as there was lack of sufficient provisions. At the end the journey became a race with death, and Burton hardly won. At Berberah, Speke, Herne, and Stroyan were awaiting him. The two latter had succeeded in their tasks, but Speke had failed. No time was lost in sailing for Aden, where Burton, not satisfied with his partial success, at once prepared for another expedition on a larger scale, Nileward, from Harar. 
On April 7, 1855, Burton returned to Berberah from Aden at the head of a party of forty-two men.

Burton and his assistants-Speke, Herne, and Stroyan-went ashore and pitched their tents, leaving the men on board. That night a fanatical force of over three hundred Somali attacked the camp, and a desperate fight followed. Stroyan was killed, Burton and Speke were wounded, while Herne escaped. Burton fought like a knight of old against tremendous odds. His cheek was transfixed by a javelin, which destroyed his palate and four back teeth. This contretemps upset the plan of the expedition, and the survivors returned to Aden in sorry plight. 
VI

HIS CRIMEAN EXPERIENCE 



\section{VI}

HIS CRIMEAN EXPERIENCE

WOUNDED and broken in health, Burton at once returned to England; he could hardly speak, and was barely able to eat, so serious were the results of the javelin thrust. His home-coming was a sad one, for his mother, to whom he was ever deeply devoted, had died in December, 1854. A course of treatment from capable surgeon and dentist soon cured him, for his blood was healthy and clean. At the invitation of the Royal Geographical Society, Burton read a paper on the Exploration of Harar, which attracted much attention and firmly fixed his fame as an explorer. 
After passing the proofs of his books Burton went down to Bath to see his father, and enjoyed a glimpse of London in Maya glimpse doubly welcome to him after his wanderings.

The Crimean War was then at its height. There was a wild rush to volunteer, and, with the return of health, Burton was caught in the flowing tide of war enthusiasm. $\mathrm{He}$ made several appeals to the War Office for an appointment at the seat of war, but could not get even a promise from the weary and harassed officials. Disgusted at this failure, he resolved to go to the Crimea on his own account and trust to chance for a post. On his way to Constantinople he stopped over at Boulogne to see his brother and sister. He much enjoyed this meeting, for his brother later became a chronic invalid owing to an injury to his head while elephant shooting in Ceylon.

At Marseilles Burton embarked for Stamboul, where he put up at the old barracks 
known as "Missiri's," kept by a former courier of Kinglake's. Burton had had some trouble in obtaining leave from the War Office for this expedition, for his brains made him no favourite in that home of stodgy routine. It was unfortunate that he was unable to obtain an appointment at first hand, for his own choice of commander was unfortunate.

During this short stay in England Burton had not seen Isabel Arundell, although she still filled his thoughts.

At Pera Burton met Mr. F. Wingfield, who was on his way to the front, and accompanied him over the Black Sea to Balaclava, where they arrived without mishap. Burton, as usual, wasted no time in delay, and went at once to the Commander-in-Chief, General Simpson, whom he had known, years before, in Scinde, as "Dismal Jimmy." This appeal for a post, however, had no result, and Burton, in despair, applied to General Beatson, a peppery old Indian officer whom he had met in Boulogne. 


\section{THE REAL SIR RICHARD BURTON}

This time he was more successful, and was appointed to "Beatson's Horse," a force of irregular cavalry, as General Beatson's Chief of Staff. At this time Beatson was organising a force of Bashi-bazouks, and Burton's executive ability and genius for organisation was most valuable to his chief. Indeed, the force was colloquially known as "Burton's Own." He worked his soldiers to the full limit of their endurance, drilled them, established a school of arms, and soon had a small, welltrained mobile force in hand-a force that might have done much and gone far.

Unfortunately the usual jealousy of camplife soon materialised.

Beatson had many enemies. Lord Stratford objected to irregular troops, as none had been present at Waterloo. The French were jealous of such a well-disciplined force, and the Turkish commanders rejoiced to see dissension among the infidel dogs. So the old pitiful envy, always present among allied forces, exiled Burton's superb force to a dis- 
tant hillside, while untrained recruits were butchered on the firing line.

Restless in the extreme, like a racer champing his bit at the post, Burton suddenly conceived a brilliant scheme for the relief of Kars and its brave inhabitants, who were suffering all the horrors of plague and famine. He had carefully matured his plan, when he roused to boiling-point by hearing that the Turks were about to be ordered to relieve Kars. Unable to restrain himself longer, he rushed off to Constantinople and laid his plan before the British Ambassador, Lord Stratford, "the great Eltchi."

Confident of the success of his scheme, and expectant of congratulations, no brush can paint Burton's savage astonishment at finding himself all at once the object of a cyclonic outburst of temper on the part of the old ambassador, who concluded a long polemic by assuring Burton that he was the most impudent man in the Bombay Army.

Years after, Burton learned what a mistake 
he had made in attempting to arrest the wheels of diplomacy, for Kars had been doomed to fall as a sacrifice to Russia's amour propre.

With disgust, tempered by a sense of humour at his discomfiture, Burton returned to find his Bashi-bazouks in bad odour with all the other forces. Indeed, they were almost in a state of siege, as the Turkish regulars were in a panic. The wily Turk sent complaints to Stamboul, and General Beatson was removed from his command.

Remonstrances and appeals proved unavailing, and at the end of September Beatson returned to England, where he afterwards brought suit against his detractors. He failed to win the action, but public opinion was in his favour. Burton, as Chief of Staff had well justified his selection.

Had Fortune been kinder, there might have been one or more brilliant cavalry charges, but the fates were against him.

Burton had a short rest at Therapia, and on 
the 18th of October, 1856, returned to England, with the eager but unavowed purpose of meeting again the maid of Boulogne.

This Crimean expedition practically closed Burton's military career. He was to gain a greater fame in other and more useful ways.

$\mathrm{He}$ himself was disappointed at not having been more often under fire, but knew that it was useless to kick against the pricks.

All things considered, he returned to London in a fairly cheerful frame of mind.

At this time Isabel Arundell wrote in her journal: "I hear that Richard has come home, and is in town. God be praised." *

* "Romance of Isabel Lady Burton," vol. i. p. 79. 



\section{VII}

\section{HIS AFRICAN DISCOVERIES}





\section{VII}

\section{HIS AFRICAN DISCOVERIES}

TN August, 1856, Burton met Isabel Arundell 1 in the Botanical Gardens by accident. She was reading "Tancred," while he was polishing some verses he had promised to his friend Monckton Milnes (Lord Houghton).

Their meeting was formal, but the dashing soldier soon managed to ascertain that she walked in the gardens every day. For a fortnight the meetings went on, both living only for the next morning when they had parted for the night. At length that which was to be, was. Burton's proposal was characteristic: he put his arm around her waist and said, "Could you do anything so sickly as to give 
up civilisation? And if I can get the Consulate at Damascus, will you marry me and go and live there?"

Her reply was equally characteristic: "I do not want to think it over-I have been thinking it over for six years, ever since I first saw you at Boulogne. I have prayed for you every morning and night. . . . I would rather have a crust and tent with you than be queen of all the world, and so I say now Yes, yes, yes!"

They both fully realised the opposition in store for them, but resolved to be firm in the face of all obstacles.

Burton now visited the Arundells as an old Boulogne acquaintance; he made a conquest of Mr. Arundell, but Isabel's mother was more difficult to please. She appears to have had some suspicion that the feeling between Isabel and Burton was stronger than surface indications showed.

For six years the roving soldier had thought of the little school-girl at Boulogne; for six 
years she had hoped and longed for a chance of seeing him again. Small wonder that she felt, as she writes, as if the moon had tumbled down and said, "I thought you cried for me, so I came."

The romance of the love story of these two lives is worthy to rank with the great romances of old. In these modern workaday times there is so much that is mercenary about the ordinary marriage, that the tale of the devotion of Richard Burton and Isabel Arundell comes like a refreshing breeze through the heavy gold-dust of the marriage mart. Their engagement was to be kept secret for a time. Nothing was to be gained by premature disclosure, and, in Burton's own opinion, he had his spurs yet to win, although to most people the pilgrimage to Meccah and the exploration of Harar would have represented a life-work.

But to Burton the great task of his life was about to present itself. $\mathrm{He}$ had conceived the idea of penetrating the mysteries of Isis ; in other words, he wished to unveil the secret 
of the sources of the Nile. It must be remembered that to this idea, and to the successful carrying out of this idea, all subsequent explorers owe their success. Burton was the pioneer of African exploration, and to his mighty brain that planned, and to his unrivalled ability that carried out his plan, the world owes more than it has yet realised.

As soon as Burton's projected expedition became known there was no lack of offers of assistance. The Royal Geographical Society made a grant of $£ 1,000$ to the expedition, the objects of which were to discover the sources of the Nile and explore the lake regions of Central Africa.

Burton, through the kind offices of Lord Elphinstone, obtained two years' leave, was allowed to take his former subordinate, Speke, as assistant, and secured the promise of his good friend, Dr. Steinhuser, to accompany him. Unfortunately Steinhuser did not reach Zanzibar in time, having been delayed by stress of weather. 
In order to impress the natives it was also arranged that a sloop of war should convey the party from Bombay to the African coast.

Burton's friends rallied about him at this time, and Cardinal Wiseman gave him a circular letter to all Catholic missionaries.

Isabel Arundell, although loath to part with her lover, recognised that great events were pending, and on the eve of his departure hung a medal of the Blessed Virgin on a steel chain about his neck.

The last fortnight that remained to the lovers soon flew. Burton kept the precise moment of leaving England a secret, and left without a formal farewell to his betrothed, other than a letter to her sister Blanche. They both realised the dangerous nature of his task, but that his absence was to last over three years they little knew, or the parting would have been still more bitter.

This expedition of Burton's, which resulted in the discovery of Lake Tanganyika and Lake Victoria Nyanza, was incomparably the 
greatest of his journeys, and the only one in which he realised to the full his original ambitious plan.

At the end of October Burton, deeply appreciative of the kindness of Lord Clarendon, Secretary of State for Foreign Affairs, who had made his expedition possible, left England for Bombay, where he picked up his assistant, Speke.

The travellers crossed to Zanzibar in the sloop Elphinstone, landing there on December 19, 1856, after a pleasant voyage over smooth and tropical seas.

Zanzibar was an unhealthy place, but in spite of this Burton decided to make the town his headquarters, for what he called a "preliminary canter," which lasted from January 5 to March 6, 1857, about the Mombas regions. The British Consul, an able man, Lieutenant-Colonel Hamerton, gave every help in his power, and was of much assistance in the way of equipping the expedition. They sailed on January 5th in the 
Riami, an old beden built by the Arabs, and made a long coasting trip. Pemba, Mombassah, and Pangani welcomed them more or less warmly, but they were glad enough to return to Zanzibar, where they both fell victims to a bad attack of coast fever.

They had, however, tasted the joy of the savage trail, and longed to start on their great exploration.

A four months' rest followed this trial trip, a period full of all sorts of preparation for the end in view, and on June 14, 1857, the Artemise, of the "Indian Navy," embarked the expedition at Zanzibar.

On June 27th Burton and Speke landed at Kaole and began their march. The expedition was badly equipped compared with the later attempts of Speke and Grant and the luxurious caravan of Stanley, but the man was the thing, and Burton was worth a dozen complete equipments. The route selected was the Arab trade route to Lake Tanganyika opened in 1825, and for the first 
fortnight they went forward at a snail's pace, the greatest care being necessary while passing through the territory of the bloodthirsty coast tribes.

Burton covered most of the ground on foot, but at intervals rode, as did Speke, on an ass, or rested in a litter borne by two men.

There were no roads, hardly a goat track was to be found, and way had to be forced through a thick and miasmic jungle. Much misery was endured from the attacks of scorpions, pismires, centipedes, and jungle lice; food was poor and scarce, and every step taken by the intrepid travellers was at the risk of their lives. Burton's spirits never failed him, and every moment of his spare time was occupied in sketching, making notes, botanical and ethnological, and in recording changes of temperature.

From June 27th to July 14th the caravan covered 118 miles.

At Dut'humi the leader of the expedition had a twenty days' bout with marsh fever, 
while Speke suffered severely from sunstroke, an illness which permanently affected him. The clear keen air of the Usugura mountains restored the travellers, and they finally reached the plains of Ugogo, ready for a rest. On November 9, 1857, they arrived at Kazeh, a plateau of 4,000 feet elevation, where Burton was gladly welcomed by the dignified Arabs of that region, a pleasant contrast to the squalid blacks among whom his lot had hitherto been cast.

A five weeks' rest at Kazeh restored the flagging energies of the two white men, and Burton collected much valuable material for his books. From Kazeh, the caravan pushed on to Yombo, and from thence to Wanyika.

On the morning of February 13th, from the top of a stony hill, a sudden view of a large body of water showed Burton that his task was finished, that Lake Tanganyika was discovered, and that in future his name 


\section{THE REAL SIR RICHARD BÜRTON}

was to rank high among the devoted band of African explorers.

A breadth of thirty-five miles suggested the sea, and Burton describes the scene as one of almost fairy-like beauty. Small wonder that he was tempted, like Xenophon, to shout, "Thalatta, Thalatta," at the sight.

The exploration of the Lake was thorough and rapid; each night was spent at a village on the coast of the great sheet of water. On April 12th Burton first set sail in a canoe on the waters of his lake, and on April 23rd the crossing occupied nine hours.

On June 20th the expedition returned to Kazeh, Burton having received the sad news of his father's death in the previous September, at Bath. At Kazeh, Burton, who was thoroughly out of health, resolved to remain for three months to recuperate, while Speke went off on a little expedition of his own, during which he stumbled on Lake Victoria Nyanza. 
In Burton's great book, “ The Lake Regions of Equatorial Africa," 1860, he fully describes the objects of his expedition, the expedition itself, and his discoveries. This is not the place to enter into a discussion as to the points at issue between Burton and Speke. Burton believed Lake Tanganyika to be the source of the Nile. Speke held tenaciously to his theory that Lake Victoria Nyanza was the true source. Whether the fact that he had stolen a march on Burton, and gone alone to this latter lake from Kazeh, and wished to claim the sole honour of unveiling Isis, coloured his theory, matters not. The fact remains that from this time on there was a rift in the lute of the old friendship. Speke suffered much from local fevers, and his almost constant delirium was responsible for the wild and childish accusations he then and afterwards made against Burton. The fact remains that without Burton's experience, executive ability, tact, and wonderful endurance, the expedition would have been 
impossible. That Speke afterwards went on another expedition with Grant is explained by the fact that he had sat at the feet of Gamaliel.

To Burton came the hard work, and to Burton is due the honour. That Burton should have remained at Kazeh was unfortunate, but that Speke could have found Victoria Nyanza without Burton's help is impossible.

Both men had a right to their own opinion, but the fact must be kept in view that Burton was responsible for the discovery of the Lake Regions of Central Africa.

It is difficult to explain Speke's later breach of faith. The travellers returned to Zanzibar in March, 1859. At Aden, Burton had a feverish seizure, and was compelled to remain. He begged Speke to wait for him in order that they might both appear before the Royal Geographical Society at the same time; but Speke, apparently influenced by the advice of the eccentric Laurence Oliphant, went to 
London, where he claimed the whole credit of the expedition, lectured before the Society at Burlington House, and lost no time in persuading the Society to initiate a new expedition with himself and one Grant at the head, leaving his chief, Burton, out altogether.

Burton arrived two weeks after Speke, to find that the cup of success had been dashed from his lips, and that he had been supplanted by a clever adventurer, who had stolen his glory. But the giant's robe hung very loosely on the dwarfish figure of the supplanter. With the subsequent expedition of Speke and Grant we have no concern, but it was reserved for Stanley, many years later, to thoroughly explore the Victoria Nyanza.

That the name of Speke has been given to a peak of the Ruwenzori Mountains by one of the latest explorers, H.R.H. the Duke of the Abruzzi, is a matter for regret, as the claims of Burton to such an honour were incomparably greater. But in the hearts of his 


\section{THE REAL SIR RICHARD BURTON}

countrymen there is a keen appreciation of Burton's motto, "Honour, not honours"-a motto that follows him after death! Better such an appreciation than a doubtful honour to a disloyal friend. 


\section{VIII}

\section{HIS ROMANTIC MARRIAGE}





\section{VIII}

\section{HIS ROMANTIC MARRIAGE}

TSABEL ARUNDELL was now to reap L the reward of her long-suffering devotion. Letters from her lover had been few and far between, and her feelings can be better imagined than described when Speke appeared suddenly in London with his impudent claim to the glory of the discovery in Africa.

A long Continental tour with her married sister had helped to pass the time of Burton's absence, but the dull ache at her heart could not be banished, and her friends complained that she talked of nothing but of African fauna and flora, and would discuss 


\section{THE REAL SIR RICHARD BURTON}

nothing but tropical and subtropical fevers. She took the keenest interest in Burton's travels, and in after-years was ever ready to break a lance in Burton's cause against his faithless subordinate, Speke.

So anxious had Isabel Arundell become in the spring of 1859 , that she had spent the season of Lent in retreat at a favourite convent of hers. She returned to the world at Easter, full of despair at the arrival of Speke without Burton, and had then serious thoughts of taking vows, but at the critical moment a verse in Burton's hand reached her from Zanzibar, and she took heart again :-

\section{To Isabel}

That brow which rose before my sight,

As on the palmer's holy shrine;

Those eyes-my life was in their light;

Those lips-my sacramental wine;

That voice whose flow was wont to seem

The music of an exile's dream.*

* "Romance of Isabel, Lady Burton." 
On May 22nd she was calling on a friend who was out, and for whom she waited. All at once a ring came and a voice resounded through the house, saying, "I want Miss Arundell's address." In another moment Burton entered the room. That moment needs the veil of Isis. Presently they went out, took a cab, and told the man to drive anywhere and everywhere!

There was much time to make up, and the pleasure of their meeting was so keen it was akin to pain.

After this Burton called regularly at the Arundells', and the question of marriage was discussed. The idea was received favourably by Mr. Arundell, but his wife would not hear of it; and the lovers were again in despair.

At this time Burton was a physical wreck. He had had twenty-one attacks of fever, had been partially paralysed, and was partly blind. He was a skeleton, and his face was a dismal yellow. 
Love, however, laughs at externals, and if Isabel Arundell had been in love with Burton's looks there would have been no marriage.

It was in speaking of Burton at this time that Lady Burton's autobiography ends, cut short by her death. The last words she wrote were characteristic: "I used to like to sit and look at him and think, "You are mine, and there is no man on earth he least like you!" ",

Isabel Arundell was as good a hater as a lover, and many enemies of her husband had bitter cause to dread that vitriolic pen so loyally faithful to her Arabian knight. They were good fighters both, but the woman was fiercer than the man when he was attacked.

Her one great sorrow at this time was her inability to nurse the man she loved. Like all good women, she had the mother nstinct strongly developed.

At this time it appears that Isabel 
Arundell made an earnest appeal to her mother to permit a marriage with Burton. Mrs. Arundell's opposition, however, was twofold. In the first place he was not a Catholic, and in the second he was more or less publicly known as an atheist-an undeserved reputation, but one which he took no trouble to set right.

The question of finance was also a crying one. Burton had been brought under the Indian Army reduction, and was not popular at the War Office.

In addition to these objections to Burton, Mrs. Arundell was naturally ambitious for her beautiful daughter, and wished her to make a brilliant match. So in one way Burton was as far removed from the fruition of his hopes as he had been in the African jungle.

At this time Burton was over forty, while Miss Arundell was twenty-nine. They might with justice be assumed to know their own minds. Burton appears to have 
urged an elopement, if a marriage between two mature persons could be called by so exciting a name, but with her strict ideas of propriety Isabel Arundell refused to take so serious a step against the wishes of her mother. If Burton had been careful of his resources he might have been more successful in persuading Mrs. Arundell to listen favourably to his suit.

He had inherited over $£ 15,000$ from his father's estate, but in money matters he was no niggard, and even a bit of a wastrel, although he rarely indulged in the fleshpots of Egypt.

One of the most remarkable things about this remarkable man was his temperance both in eating and drinking. He was wise enough not only to know but to act upon the knowledge that any self-indulgence would be fatal on journeys where an attack of tropical fever comes like a cyclone upon the unsuspecting white man, who can only resist if his blood be not over-alcoholised 
or free from the stagnation induced by gluttony.

After nearly a year of uncertainty and strain, Burton went off suddenly to America to explore the country of the Mormons, leaving a note for Miss Arundell in which he told her he had resolved to give her nine months to think over the matter alone, and that on his return he should expect a definite answer. $\mathrm{He}$ was very tired of Mrs. Arundell's one answer to her daughter's prayers, "Richard is not a Christian, and has no money," as both counts of the indictment were untrue.

Burton put the matter plainly in his farewell note. He wrote that Isabel must choose between her mother and himself, that she must make up her mind within the next few months, and that if she would not marry him then he should go back to India, organise other expeditions, and remain there permanently. If the marriage had not taken place, geography might have been 
the gainer, but it is hard to think of the Haji as a solitary figure. The fame of "Captain and Mrs. Burton," as they are still called in Syria, is not the fame of one or of the other, but the fame of both.

Fortunately Destiny was shaping the rough-hewn ends of their lives in a happier mould.

After Burton's departure Isabel had a serious illness, and was for some time delirious. She was physicked for every known disease, but she was only heartsick, and weary of the long strain. She knew she was to marry a poor man, and at the critical moment did not wish to be found wanting, so when she grew better she went down to a country farmhouse, where she learned cooking and housework. Later on she also learned to fence, in order to please her betrothed.

Burton, meanwhile, was careering over the United States, bent on solving the mysteries of the Mormons. His book 
"The City of the Saints," 1861, is the most illuminating book on the Latter Day Saints ever written. It is the work of a trained investigator, the work of one who knew.

At Salt Lake City Burton made friends with Brigham Young, and found him a shrewd and hard-headed old farmer of parts.

Wherever Burton went he seemed to have the knack of getting at the heart of the artichoke. He never wasted time with underlings, but always went straight to headquarters.

In the comfortless days of 1860, when the Indians were "out" in Nebraska, a journey such as Burton's was very different from the painfully luxurious American travel of to-day. But Burton, fresh from the perils of Central Africa, laughed at the discomforts of Yankee journeying.

He started from St. Joseph on August 7, 1860 , in a prairie waggon, and was jolted 
away over the endless and dreary plains. It was not a comfortable conveyance, and the passengers grumbled constantly. Burton, as usual, managed to extract a great deal of information from his fellow-travellers, one of whom, an Indian known as "Bob-tailed Coyote," was officially called by the United States Government Robert T. Wolf; and by the time he reached Salt Lake City was well knowledged as to the salient points of Mormonism. One of his companions on the journey, a Lieutenant Dana, introduced Burton to several of the leading elders, and he proceeded to explore the place with the same keen interest he had shown in Meccah. $\mathrm{He}$ notes with regret the fact that many of the newest recruits were young and pretty English girls, who quickly lost their colour in the corroding climate of the States.

In those days United States troops were not allowed to approach nearer the city than a distance of forty miles, and Burton much enjoyed a visit to Camp Floyd in an 
American trotting waggon drawn by a pair of mules. He also explored the Cañons, and after three weeks at the American Holy City, went on to the gold diggings near Carson, at the foot of the Sierra Nevada. He covered the distance, about 570 miles, in a mail waggon and enjoyed the experience, which lasted a month. About November 1st he went on to Sacramento and San Francisco, and then home by way of Panama. With his usual thoroughness, Burton had applied to Brigham Young to admit him as a Mormon, but the old man was too shrewd to give away his secrets to such a keen outsider. In all Burton travelled about twenty-five thousand miles in America.

Isabel Arundell was spending Christmas with her cousins, Sir Clifford and Lady Constable, at Burton Constable (a happy omen), when one morning at breakfast her eye caught the announcement in the Times that Captain R. F. Burton had returned from America. All that night the excited woman sat up, 
packing feverishly, inventing excuses to get away, and wondering when a letter would come.

Two came the next morning, and one can imagine the welcome that was given them, for Isabel Arundell had made up her mind.

Within twelve hours she had managed to get a wire from London recalling her to town, and she hurried to the station in a mixture of triumph, trepidation, and glee.

When they met they talked seriously and long. They both felt they had waited long enough, and they refused to postpone entering into their kingdom. They arranged to be married at the end of January, 1861.

Isabel told her parents of their plan, not mentioning the exact date. Her father at once consented, but Mrs. Arundell said, "Never."

Isabel, however, was now adamant where her love for Burton was concerned, and replied, "Very well, then, mother ; I cannot 
sacrifice our two lives to a mere whim, and you ought not to expect it, so I am going to marry him whether you will or no."

Her brothers and sisters sympathised with her, and her mother finally offered her a marriage with her father and brothers present, an offer Isabel resolutely declined. In despair she went to Cardinal Wiseman, who asked her to leave the matter in his hands. He asked Burton to give him three promises in writing. These promises Burton was very glad to sign.

1. That Isabel should be allowed the full and free exercise of her religion.

2. That any children should be brought up as Catholics.

3. That the marriage should take place in a Catholic church.

After this the Cardinal promised to obtain a Papal Dispensation from Rome, and to perform the ceremony himself. He also saw Mr. Arundell, who explained his wife's position, and informed the Cardinal that as she 
was threatened with paralysis nothing must be done to excite her.

Accordingly it was decided that the marriage should take place very quietly in the presence of friends only, and that the news should be broken gently to Mrs. Arundell afterwards. Isabel was to go away on a visit to some friends to prevent any suspicion on her mother's part.

She spent the three weeks before her wedding very quietly, preparing for the crown of her hopes. Her state of mind is shown by her reflections at that time.

"The principal and leading features of my future life are going to be:-

Marriage with Richard.

My parents' blessing and pardon.

A man-child.

An appointment.

A little society.

Doing a great deal of good.

Much travelling." *

* “The Romance of Isabel, Lady Burton," vol. i. p. 161. 
Burton spent the three weeks before his marriage chiefly in the British Museum.

On Tuesday, January 22, 1861, Isabel Arundell was married to Richard Francis Burton at the Bavarian Catholic Church in Warwick Street, by Dr. Hearne, the Vicar-General of Cardinal Wiseman, who was ill.

That there was no issue to this marriage was ever a great trial to both Burton and his wife. Despite the opposition of the Arundells it was the wisest possible marriage for Isabel. She married a man who needed her as much as she needed him. Can there be a more successful marriage?

After the wedding the happy couple went back to the house of Burton's old friend Dr. Bird in Welbeck Street for the breakfast. At table Dr. Bird began to chaff Burton, and at length said, "Now, Burton, tell me, how do you feel when you have killed a man?" Burton's reply was characteristic: " $\mathrm{Oh}-$ quite jolly, Doctor-how do you?" 
After the wedding breakfast Captain and Mrs. Burton strolled down Welbeck Street to Burton's lodgings in St. James's and took up housekeeping without any fuss whatever-a happy ending to the long romance.

Burton's letter to Mr. Arundell after the marriage is a model in its way. It shows the man at his best, and is a mental photograph :-

$$
\begin{aligned}
& \text { "January 23, } 1861 . \\
& \text { "Burix Street, } \\
& \text { "Str. James's. }
\end{aligned}
$$

"Mr deAR Father,-I have committed a highway robbery by marrying your daughter Isabel at Warwick Street Church and before the registrar-the details she is writing to her mother.

"It only remains for me to say that I have no ties or liaisons of any kind, that the marriage was perfectly legal and respectable. 


\section{HIS ROMANTIC MARRIAGE 133}

"I want no money with Isabel; I can work, and it will be my care that Time shall bring you nothing to regret.

"I am, "Yours sincerely,

"Richard F. Burton." 



\section{IX}

\section{HIS CONSULATE AT FERNANDO PO}





\section{IX}

HIS CONSULATE AT FERNANDO PO

No more was Burton to fight alone, no more was he to suffer the slings and arrows of outrageous fortune-with Isabel Arundell ever ready to interpose with shield and buckler.

When Mrs. Arundell was informed of the marriage she behaved very well, knowing that the inevitable had happened. In later years she became very fond of her famous son-in-law.

The first night that the happy pair dined with the Arundells there was a painful restraint and deadly silence. At dessert Burton was so nervous that he 


\section{THE REAL SIR RICHARD BURTON}

forgot to push the decanter on when it came to him ; suddenly a still small voice came from one of the children who had come down for dessert and whose idol was a slangy midshipman brother: "I say, old bottle-stopper, pass the wine." Burton roared with laughter, and the ice was broken for good. From that time on he was on the best of terms with his wife's family.

A busy time followed. Captain and Mrs. Burton took their place in Society and introduced each other to their numerous friends. Lord Houghton got Lord Palmerston to give an evening party for Mrs. Burton, at which she was the bride of the evening; he also introduced Burton and his wife to many of his own friends. Mrs. Burton was presented "on her marriage" by the Dowager Lady Russell, and allowed to put her name down for a Drawing-room. In this way the social position of the Burtons was settled for good and all. In later years it was matter for complaint at several 
British Embassies to Foreign Courts that so much royal notice was shown to a mere consul and his wife!

About this time the famous fire at Grindlay's, the Indian Agent's, destroyed nearly all Burton's worldly goods, including some priceless Persian and Arabic manuscripts.

After seven months of bliss, the question of ways and means began to press, and Burton decided to enter the consular service. Because his mastery of Eastern languages, added to his knowledge of Orientals of all races, would have been, in the Orient, of untold value to his country; he was offered, and compelled, on account of his lack of resources, to accept, the consulship at Fernando Po, on the West Coast of Africa, a desolate coast with a deadly climate, known as the "Foreign Office Grave." No white woman could live in that poisonous air, and Burton knew that the post would entail a separation from his bride, although in another 
way the post would be their best friend, enabling them to write daily. So anxious was he, however, to begin consular work that he accepted the position at a salary of $£ 700$ a year, and the promise of almost certain death. Absurd as it may appear, he was grateful to Lord John Russell for obtaining the appointment for him.

In any other country his successful explorations would have brought rich recognition, but the England of that day disliked clever men. They were always "uncomfortable," and made the Secretaries of State think.

Unfortunately Burton had failed to secure the consent of the Indian Army authorities to the acceptance of his new post, and his enemies-the "office rats of Bombay"-lost no time in having his name struck off the Indian Army list, although several young fools had, through influence, been allowed to remain in both services. Burton protested keenly and logically, but to no effect. The private pique of a few jaundiced bureaucrats 
outweighed all Burton's services, and at the age of forty his only assets were his rank of captain, his fame as an explorer, and a devoted wife, with a third-rate consulship in a deathly climate. It was like starting life again, when life was half over.

In August, 1861, a sad and gloomy couple bade each other farewell at Liverpool.

Isabel had made various appeals to her husband to be allowed to accompany him, but he, mindful of the dangers of the climate, refused. It was arranged that she might perhaps come out later to meet him at Madeira or Grand Canary, and with this small consolation she had to be content. On board the boat Isabel unpacked her husband's cabin things, settled him comfortably, and saw that he was provided with plenty of change for the voyage. Like most great men, Burton was, as a rule, short of ready money in his pocket.

It was blowing hard and raining, but the weather seemed to be in sympathy with the 
lovers-wedded now, but always lovers-and the world was gray. Burton wrote long after that that parting was the darkest of his life, and he crept sullenly to bed with the roar of the storm in his ears, too miserable for even his customary "nightcap."

As usual, Burton began notes for the inevitable book "Wanderings in West Africa," 1863.

At Fernando Po Burton plunged at once into his new duties. He found that the local negro had much too big an idea of his own importance, and promptly proceeded to teach him a lesson.

A couple of days after his arrival Burton was in the Consulate, chatting with several other Englishmen, when a big black buck negro stalked in, and with the staccato "Yawyaw" laugh of the tribe, clapped Burton on the shoulder and blurted out, "How do, Consul? Come to shake hands-how do?"

Burton gave one look, then called his Kroo boys in and had the impudent fellow thrown 
HIS CONSULATE AT FERNANDO PO 143

out of the window. It was only a four-foot fall, but Burton's attitude was understood, and he had no more trouble with the blacks.

When Burton had landed on September 26 th he saw that his only chance of health lay in regular occupation and very moderate living. He looked about at once for a health resort in the hills, where he might retreat for rest and recuperation, and soon found a place above Sta. Cecilia, 800 feet above sea-level, where the air was pure, and free from coast fever. The Consulate proper was down in the slums of the town of Sta. Isabel, near the sea, and was an impossible abode.

As Burton's consular jurisdiction was so large, he made numberless trips up and down the coast, and was seldom long in one place. The old gipsy restlessness was more strongly developed than ever at this time. One of his first expeditions was to Abeokuta, and H.B.M.'s Consul at Fernando Po was directed to lecture the chief upon his blood- 


\section{THE REAL SIR RICHARD BURTON}

thirsty ways, and to intimate that force would be used if necessary.

A week was spent in the capital, and then followed an official visit to the Bonny river in H.M.S. Bloodhound. A severe attack of fever frightened Burton at this time, and sent him off to the Cameroons to rest. Here he did some mountain climbing, and wrote several articles on the health-giving qualities of the place.

The remainder of the winter was taken up by consular journeys and literary work. $\mathrm{He}$ happily escaped the yellow fever that at this time killed many Europeans in the town of Sta. Isabel.

In March he went on a longer trip than usual to the Gaboon, where he hoped to bag a specimen of the gorilla. He had just read Du Chaillu's book, and was much interested in the country. He was unfortunate, however, and did not succeed in shooting one.

His trip was trying in many ways, for he 
was nearly drowned in the Gaboon river, and the next day was struck by lightning.

There were very few experiences unknown to Burton in the way of adventure. His book on this and other expeditions made from Fernando Po was "Gorilla Land," 1875.

The following year he made an expedition to the Lower Congo, and ascended the stream for some distance in a canoe and enjoyed the sight of the wonderful cataracts. $\mathrm{He}$ read a paper on this expedition before the British Association in 1864, and he was recognised as one of the pioneer explorers of the Congo.

After a separation of eighteen months, Isabel Burton, who had been fretting over her husband's absence, had a sharp attack of diphtheria, and on her recovery went to the Foreign Office, and broke down during an interview with Mr. (afterwards Sir Henry) Layard, in which she begged for leave for her husband, on the ground of health. The appeal of a beautiful woman 
in tears prevailed, and a despatch was sent off to Burton giving him four months' leave.

In December Burton returned, and a very happy Christmas was spent at Wardour Castle, the seat of Lord Arundell, followed by a visit to Garswood, where Isabel's uncle, Lord Gerard, always gave the romantic couple a hearty welcome.

The short leave expired in a round of gaiety; but this time Isabel refused to be left at home, and it was arranged that she should go as far as Teneriffe with her husband on his return to his dreary Consulate.

In January, 1863, the Burtons sailed from Liverpool on the s.s. Spartan. They ran out with a tremendous gale, and were for some time in danger from the enormous seas that came aboard. In due time they landed at Funchal, and spent a happy, lazy time in the poppy-land of Madeira, their first real honeymoon.

For two months they explored the island 
thoroughly, and early in March embarked for Teneriffe.

They wandered over the country, sleeping in wayside huts, and revelled in the pure, exhilarating air.

At Santa Cruz they parted again, Burton returning to his Consulate at Fernando Po, while Isabel, with heavy heart, took ship for England, resolved to move Heaven and earth to get her husband promoted to some post where she could live with him.

During the next fifteen months the unhappy married lovers met at Teneriffe whenever Burton could snatch a short holiday.

In November, 1863, Burton was appointed Special Commissioner to the King of Dahomé, to arrange certain matters in dispute with that dark potentate and to convey gifts from the "Great White Queen." His experiences are related in his book, "A Mission to the King of Dahomé," 1864.

The King took a liking to Burton, and 
made him a brigadier-general of his brigade of Amazons.

How well the Consul performed his mission is shown in the following letter from Lord Russell to Mrs. Burton:-

"Minio,

"October 6, 1863

"Dear Mrs. Burton,-I know the climate in which your husband is working so zealously and so well is an unhealthy one, but it is not true to say that he is the smallest of the consuls in the worst part of the world. Many have inferior salaries, and some are in more unhealthy places. However, if I can find a vacancy of a post with an equal salary and in a better position, I will not forget his services. I do not imagine he would wish for a less active post. He has performed his mission to Dahomé very creditably, to my entire satisfaction.

"I remain,

"Yours truly,

"Russelu." 
In August, 1864, Burton was allowed to return home again on leave.

During this time came the famous meeting of the British Association at Bath and the tragic incident of Speke's death.

Burton and Speke were both to address the meeting, and an exciting time was anticipated, for the points in dispute between the two men were to be thoroughly threshed. out.

Unfortunately Speke, while out shooting, met with a fatal accident.

Burton was thoroughly unmanned, and never spoke a harsh word of Speke after this shocking incident.

In the early winter of 1864 the Burtons went on a two months' driving tour in Ireland, and visited many country houses.

At this time Isabel brought great pressure to bear on Lord Russell, then Foreign Secretary, as she could not bear the idea of another long separation.

At last she was successful, and Burton 


\section{THE REAL SIR RICHARD BURTON}

was promoted to the Consulate of Santos, in Brazil. The climate, although not healthy, was bearable, and Isabel could at last live with the husband who was also her lover.

A complimentary dinner was given to Burton on his promotion by the Anthropological Society, and Lord Stanley (afterwards Lord Derby) made a generous speech of congratulation to the guest of the evening.

The happiness of the Burtons was now complete, and they arranged for a short holiday jaunt in Portugal before starting for the daughter country. 


\section{$\mathrm{X}$}

\section{HIS CONSULATE AT SANTOS}





\section{$\mathrm{X}$}

HIS CONSULATE AT SANTOS

BuRTON and his wife, to the casual observer, were like brother and sister; the real camaraderie between them was singularly complete, and often the Haji would return from his club declaring that his wife was the most clubable man he knew.

The voyage to Lisbon, although made in rough weather, was enjoyable, for no long separation loomed up at the other end. For two months the Burtons roamed over Portugal in a lazy but thorough way, leaving no stone unturned in delving beneath the surface manners and customs of the country. 


\section{THE REAL SIR RICHARD BURTON}

They saw a bull-fight, because Burton thought everything, bad or good, should be seen once, but they did not form the habit. After the holiday tour Burton sailed from Lisbon for Rio, while his wife returned to London to "pay, pack, and follow." All through her life Isabel Burton was the payer, the packer, and the follower, and her husband's fame owes much to her untiring zeal in his behalf. The joy of fighting never failed this intrepid woman, and any attack on her husband found her ready and waiting to confound the lies of his enemies.

As she was very literal, and had promised her husband to take the first boat to England after his departure, Isabel sailed a few hours after Burton in a little tub of 428 tons. She had a bad time in the Bay of Biscay, but arrived safely in due course after an eight days' voyage. A month in England sufficed for all necessary labours, and at the end of that time a very cheerful woman sailed 
from Southampton to be with her husband for good and all, until that dreary day in the far-off nineties at Trieste, when Richard Burton, as usual, and for the last time, went on ahead. The voyage was pleasant, but at Pernambuco Isabel found all the letters she had written to her husband undelivered, and passed a miserable evening, as she knew he would be wondering what had become of her. However, husband and wife met at Rio a few days later, and at once proceeded to explore the town socially, commercially, and politically.

Dinners, receptions, and picnics were the order of the day. The British Minister, Sir Edward Thornton, and his wife were very kind, and the new life promised well. The Burtons were an attractive couple, and drew an unusual amount of attention whenever they appeared in public together.

At Rio Mrs. Burton had her first attack of fever, fortunately a slight one.

The new Consul and his wife arrived at 


\section{THE REAL SIR RICHARD BURTON}

Santos on October 9, 1865, and were not charmed with their first impressions of the place. It was really a swamp by the sea, where mosquitoes, scorpions, and centipedes held high carnival. Fortunately there was a most capable Vice-Consul who was fond of routine work, and whose real liking and admiration for Burton left the great traveller free for any further explorations he might plan.

As Santos was so unhealthy, the Burtons lived chiefly at Sāo Paulo, the capital of the province, about eight miles inland, up in the hills, where they rented a disused convent, a long, low, picturesque building in the Rua do Carmo, where for the first time Burton had a home of his own. The life on the Brazilian hills was ideal. Burton and Isabel rode, studied, fenced, and walked together. Burton's mastery of Portuguese made him persona gratissima not only at Court, where Dom Pedro made much of him, but in the huts of the peasants and the camps of the 
navvies. During the first eighteen months life was more or less quiet for the restless explorer. $\mathrm{He}$ travelled, indeed, all over his own province of Sāo Paulo and spent a cheery Christmas at Rio, where he had audience after audience with the Emperor who was fond of the company of clever and famous men.

Burton, however, longed for fresh fields and pastures new; and on June 12, 1867, he and his wife started on a long journey, to include a visit to Minas Geraes, a trip to some gold-mines worked by Englishmen, and a rather dangerous expedition in canoes down the Sāo Francisco river.

On this journey of two thousand miles, which occupied five months, over eleven hundred miles were done in an ajojo, a native craft, half raft, and half canoe. The time occupied was five months, and the usual book made its appearance later,"Explorations of the Highland of Brazil," 1869. For two months husband and wife 
travelled together by coach and on mule back, enjoying the tropical scenes, and on August 7th Burton bade farewell to his wife and a party of friends at Sabará, and started alone on his adventurous canoe trip.

The boat was of curious construction, with its standing awning, some seven feet high, pitched like a tent upon two hollowed $\log$ s.

Under the awning was a rude boarded bed, a table and tall desk; while in the stern was a small galley lined with bricks -a Cunarder compared with some of Burton's African boats. A crew of three steered Burton safely through the whirlpools, rocks, sand-bars, swags and rapids of the winding stream. Visits to different ranches and haciendas made a diversion from day to day, and new scenes stilled the gipsy longing in the blood of the traveller for change. Seven books were his constant companionsHorace, Martial, Hafiz, and Camoëns, the 
Bible, Euclid, and "The Bard." The constant perils from climate, Indians, wild beasts, river dangers, and venomous insects only added to Burton's keen sense of enjoyment in the wilds.

The river journey ended at Varzea Redonda, where he explored the Falls of Paulo Affonzo, the Brazilian Niagara. From here he went to the Porto das Piranhas, on to Bahia and Rio, and so back to Santos, which he called the "Wapping of the Far West."

During the journey Burton had enjoyed wonderful health, but on his return he was prostrated by a mysterious malady that caused the most agonising pain and yielded only to the old-fashioned remedies of bleeding and blistering, helped out by native drugs.

After his convalescence at a village by the sea, Burton began to get thoroughly tired of the dull routine of the Consulate at Santos, and had serious thoughts of leaving 
the consular service, but his wife's advice prevailed, and he promptly reaped his reward.

In 1868 Brazil and Paraguay had been at war for some time, and the Foreign Office asked for definite and authoritative information as to the exact situation.

Lord Stanley accordingly granted Burton sick leave, with orders to report on the operations at the seat of war in Paraguay. This suited the Consul, and he at once broke up his establishment at Sāo Paulo and sent his wife back to England with a bundle of manuscripts for publication. He had definitely decided not to return to Santos again, but fortunately he did not find it necessary to announce this decision. $\mathrm{He}$ planned to visit both Uruguay and the Argentine, to cross the Andes to Peru and Chili, to go by the Straits of Magellan to Buenos Ayres and so back to England.

In August, 1868, he sailed from Rio for 
Monte Video, and had a wearisome voyage of five days in a dirty small boat, a voyage which only his Horace made endurable. In addition to his book on Brazilian exploration, Burton afterwards brought out two more works which owed their inception to the Portuguese Empire in South America-" The Lands of the Cazembe," 1873, and "Iraçema, or Honey Lips," 1886.

After a week at Monte Video, Burton started off for the battle-fields of Paraguay, stopping at Buenos Ayres, the Chicago of the South, where he noted the all-prevailing odour of embalmed beef, at Paysandu and at Rozario, famous for its hairless dogs, known as remedios. After a most careful and exhaustive study of the battle-fields, particularly of Cumzu, Cumpaity, and Humaita, where one of the Brazilian officers lent him his own chargers, Burton crossed the pampas and the mountains to Chili and Peru. While sitting in a café at Lima he chanced to hear of his appointment to 
the Consulate at Damascus, and hurried home to England.

Nor had Isabel Burton wasted her time in London. She had seen several of her husband's volumes through the press, had worked hard, and as it proved successfully, for his promotion, and succeeded in getting a letter of apology from Sir Roderick Murchison, the then President of the Royal Geographical Society, for the omission of Burton's name from a list of Central African explorers in an address; a letter in which Sir Roderick paid Burton the highest compliments.

In this letter, dated November 14, 1869, the President of the Royal Geographical Society said inter alia :-

"If you will only refer to the twentyninth volume of the Journal of the Royal Geographical Society you will see how, in presenting the medal to your husband as the chief of the East African Expedition, I strove to do him all 
justice for his successful and bold explorations." *

So mote it be.

The Burtons were now at the zenith of their career. Lord Stanley (afterwards Lord Derby) had appointed Burton to the Consulate of Damascus at a salary of $£ 1,000$ a year, but when Disraeli's first short Ministry went out of power Lord Clarendon became Foreign Minister in succession to Lord Stanley, before Burton's return.

Burton's enemies-and there were many whom he had offended by his contemptuous treatment of their petty claims to attention - had objected strongly to his appointment by Lord Stanley, but to no effect; they now, however, made a renewed and savage onslaught. They represented to Lord Clarendon that Burton's appointment would be unpopular both with the Moslems and with the Christian missionaries in Syria.

* "The Romance of Isabel, Lady Burton," vol. i p. 356." 


\section{THE REAL SIR RICHARD BURTON}

As a matter of fact no man could have been more popular both with the Moslems and with the best class of missionaries in Syria. The scholarly Americans of the older generation at the famous College of Beyrout, Dr. Daniel Bliss and Dr. Post, were always on good terms with Burton. The miserable little clique of British Syrian missionaries, however, headed by the egregious Mr. Mentor Mott and the drunken Consul-General at Beyrout, on the other hand, always hated and feared Burton, for he knew thoroughly their hypocritical and shallow schemes; he understood that a badly simulated zeal for converts only half concealed a very real desire to line their own pockets. For the manly missionary Burton had the highest respect; for the wolf or the fox in sheep's clothing he had the contempt and loathing felt by all decent men for the slimy Stiggins and the corrupt Chadband.

Burton's attitude towards missionaries has 


\section{HIS CONSULATE AT SANTOS 165}

been so often misrepresented that it is necessary to use plain words. He was popular with the honest missioner; with the others he was not. 



\section{XI}

HIS CONSULATE AT DAMASCUS 



\section{XI}

HIS CONSULATE AT DAMASCUS

THE Consul at Damascus was in 1869

1 a more important personage than he is to-day. He had a wide jurisdiction over British subjects in several provinces and was responsible for all British missions, schools, and commerce; in fact, he really occupied a more important position than the Consul-General at Beyrout. It was a distinct step from Santos to Damascus.

When Burton arrived from South America, he had an interview with Lord Clarendon, and showed the Foreign Minister how futile and feeble were the objections to his appointment. Clarendon listened to Burton, 
and gave him to understand that if he did well he might in time get Morocco, Teheran, and Constantinople, for all of which posts he was the ideal man.

The Burtons were fêted everywhere in London during the spring. It was felt that at last the right man was in the right place, and that a famous Oriental scholar was to hold an Oriental post. No hint of the miserable missionary scheme to have the great explorer recalled was then in the air. Plots against Burton as a rule grew rankly, like toadstools in a noisome cellar, during his absence; when he was at hand his enemies slunk to kennel like whipped curs.

In the later spring the Burtons crossed to Boulogne and lived over again the old romantic days when Miss Arundell first met Captain Burton on the ramparts. As they grew older these happy lovers grew more romantic, and it is a moot point whether Isabel grew more like Burton or Burton more like Isabel. 
As the Consul's leave drew near its close he went to Vichy to do the cure, having decided to go on from there to Damascus by way of Brindisi and Beyrout, while his wife went back to England to "pay, pack, and follow." Isabel worked hard in England, seeing her husband's books through the press and taking lessons in the theory and practice of boring "tube-wells," for use in the desert, as well as learning how to take to pieces and put together all kinds of firearms.

She had rather a tragic journey to Damascus, as she lost two of her nine boxes on the way, one containing some $\& 300$, all her ready money. However, she sailed from Marseilles on the old P. and O. Tanjore and trans-shipped at Alexandria to the Ceres which landed her safely at Beyrout, where she took one of the French Company's landaus for the long drive to Damascus. The Burtons later made Beyrout their Biarritz and enjoyed a change occasionally to the sea air. 
When Isabel reached Damascus she found her husband living uncomfortably at an inn, and at once began house-hunting. Nothing irritated her so much as to see her hero in any discomfort, and when she was with him he lived in all the ease a clever, capable woman could provide-and that ease leaves little to the imagination.

To show the spirit in which Burton entered upon his new and congenial duties, follows an extract from his letter to Lord Clarendon upon taking up his appointment:-

"I now renew in writing the verbal statement in which I assured your lordship that neither the authorities nor the people of Damascus will show for me any but a friendly feeling; that, in fact, they will receive me as did the Egyptians and the people of Zanzibar for years after my pilgrimage to Meccah. But, as designing persons may have attempted to complicate the situation, I once more undertake to act with unusual prudence, and under all circumstances to hold myself, 
and myself only, answerable for the consequences." *

Burton did not receive his exequatur (Barat) and Firman until October 27th, but before that date he exchanged visits that were not official with the Wali, or Governor-General, of Syria, Rá'shid Pasha, for whose oily personality Burton speedily contracted a wellfounded dislike and distrust.

The dignitaries of the Eastern Churches hastened to call on him, as did the leading Moslems and the principal Christians, including the Bishops of the Greek Orthodox, Syrian Orthodox, and Syrian Catholic Churches. The Russian Archimandite, the Shaykh el Ulemá, the Shaykh el Molawiyyeh, the President and Vice-Presidents of the Damascus criminal court, and numerous others of light and leading. A great friend of the Consul's was the exiled Abd-el-Kadir, who, like him, was a Master-Sufi. The fact that the Chief of the Ulemá, Abdullah Effendi

* Lady Burton's " Life," vol. i. p. 469. 


\section{THE REAL SIR RICHARD BURTON}

el Hálabi, a most learned orthodox and leading Moslem, called first upon Burton and remained for fifty minutes ; without waiting, as was usual, for the Consul to call on him, shows how absurd were the charges that Burton would be persona non grata to the Moslem world.

Isabel Burton's house-hunt had proved a success, and the Consul and his wife were soon installed just under the Jebel Kasún or Camomile Mountain, in a quaint Kurdish village, the suburb of Salahiyyeh, where they furnished a charming house so charmingly that it has been immortalised in a picture by Lord Leighton. Here, for two years, they received a constant stream of famous people, and dispensed a generous and discriminating hospitality. A more imposing dwelling could easily have been obtained in Damascus. But the Burtons disliked the shut-in feeling they always had in a town where the gates were closed at sunset; they much preferred a moonlight gallop in the desert to a formal dinner or reception. 
The life at Salahiyyeh was patriarchal. Isabel doctored the bodies and endeavoured to heal the souls of the motley population of the village, while Burton's unique knowledge of Eastern tongues and customs soon made him an informal arbiter in tribal and religious disputes.

As time went on it is hardly too much to say that the Burtons ruled the place, and their rule was extending over the country and in Damascus itself when the crash came.

Mrs. Burton's salon became famous. Her drawing-room and terrace became a neutral meeting-ground for all tongues, all religions, and all beliefs. No British Consul in a great Oriental town ever had half the power or influence wielded by Richard Burton, and had the Foreign Office appreciated the benefit to British prestige gained by his exertions the whole history of British policy in the Near East could have been different; England might have had an ambassador at Constantinople who would have had the ear not only 
of the Commander of the Faithful, but that of the Shaykh-ul-Islam as well.

With one class in Damascus Burton was at once on bad terms. He would have nothing to do with the Jewish money-lenders who flourished there under British protection, and declined to allow his Consulate to be used as a debt-collecting agency. The Hebrew usurers resented this, as they had found earlier consuls more pliable, and at once began to plot for his recall. Indeed, this was the foundation of that unholy alliance between the Shylocks of Damascus and the pitiful British missionary cabal at Beyrout, the alliance that ultimately resulted in the recall of the most brilliant and successful consul Great Britain had ever had in the Orient.

One of Mrs. Burton's protegés was the successor of Lady Hester Stanhope, the wellknown Lady Ellenborough, Jane Digby, who afterwards married the young Shaykh el Mezráb, and lived for half the year a wild desert life among the Bedawi. This clever 
but unfortunate woman had been more or less unjustly attacked by certain missionaries, and Isabel Burton, in her usual impulsive way, warmly espoused her cause. That Jane Lady Ellenborough was eccentric is undoubtedly true; that any more serious charge could be proved against her is improbable.

No sooner was Burton settled than he began to plan an expedition to Tadmor, the ancient Palmyra. A consul in an Eastern town at that time ranked locally like a minister to a small court, and was expected to keep up a certain amount of state. This appealed rather to the Consul's wife than the Consul, for Isabel Burton was ever a grandedame.

The question of this particular expedition was a serious one. The wells in the desert belonged to Lady Ellenborough's tribe, and with a pathetic but praiseworthy loyalty to her husband's kinsmen she tried, for their benefit, to make as much as possible from all travellers who passed that way. The usual 
charge for so-called "protection" was over $£ 200$, but Burton objected to paying what he justly regarded as blackmail, and determined to go as he pleased, with little reference to the somewhat visionary dangers of the journey.

Lady Ellenborough was greatly disturbed at this consular flouting of the traditional right of her tribe to levy tribute on travellers. Tadmor, or Palmyra, was about 160 miles out in the desert, and as all previous travellers hadl gone with a large party from the tribe of El Mezráb as an escort for protection, Burton was anxious to break up this practice of organised blackmail, and did it in his characteristic, strenuous way.

Lady Ellenborough did not like the Consul's refusal, and warned Mrs. Burton of the dangers of the desert. At length she persuaded the Consul to take one of her kinsmen as scout to show the wells and warn off all raiders. The real object of this man's presence was, of course, to lead the party into an ambush, where they would be held until 
ransomed, but Burton was quite keen enough to suspect the object aimed at, and kept the man a prisoner until the party had safely returned to Damascus.

The usual books appeared in due course"Proverba Communia Syriaca," 1871, and "Unexplored Syria," 1872-while Mrs. Burton wrote an interesting volume on "The Inner Life of Syria," which appeared in 1872.

Spring and winter were delightful in the Kurdish suburb, but the summers were too hot, and Burton lost no time in finding the usual Alpine retreat where he could recuperate and rest, although his "rest" was hard work to the average man. He was ever working, either polishing his acquired knowledge or learning something new. His favourite saying was "Ex Africa aliquid semper novi," and the discoveries of successive explorers who took the pearl from the oyster he had opened, pleased him mightily, as proving the truth of his maxim.

For their villegiatura the Burtons chose 
the village of B'ludan in the Anti-Lebanon, where the mountain air blew in fresh and sweet. Miss Stisted calls their house "a large limestone barn."

The life was primitive in the extreme, and in a short time the Consul and his wife became the idols of the people. While living here, Isabel Burton was insulted by the half-crazy son of a local Shaykh, whom she spiritedly slashed over the face with her whip. This act was necessary both to protect herself and for the sake of British prestige, but it was afterwards used in a twisted and distorted fashion by the usurer-missionary conspiracy as a weapon against the Consul.

Burton took great interest in Baalbek during his term of office, and made various unavailing attempts to impress upon the lazy and venal Wali the necessity of keeping the noble ruins in repair. A narrow escape from the Bedawi, while on a fifteen days' journey of desert exploration with his friends Drake and Palmer, only 
amused the veteran traveller, who declared that he felt highly complimented that some three hundred Arabs should have been sent to capture three Englishmen. A visit to Jerusalem with Drake and Palmer, Charles Warren and the learned Orientalist Ganneau, gave opportunity for some interesting study of the topography of the Holy City. From Jerusalem Burton and his wife made a tour of the country, including Bethlehem and Jericho; while at Nazareth there was serious trouble.

While Burton's party was in camp outside Nazareth, near some other travellers, a thief entered one of the tents and was kicked out. As this happened, the congregation of a Greek Orthodox Church near by unfortunately came out, and promptly joined in the fray. There was soon a regular riot; several of Burton's servants were injured and his sword-arm hurt. He himself made no move, but marked out the ringleaders for arrest later on. Finally he fired 
in the air as a signal for help to the neighbouring camps, and the cowardly Greeks, as usual, fled. The Greek bishop, who was a personal enemy of the Consul, because Burton had refused to recognise the fraudulent transfer of a Jewish synagogue which this wily prelate-one Niffon, a great scoundrel-had purchased from the Turks, sent a lying report to Constantinople, which later did Burton great harm.

After this incident a missionary trouble arose. A certain Mr. Mentor Mott, who was a man of pious fervour but unquestionably somewhat mentally deficient, appeared at Damascus. $\mathrm{He}$ was so eccentric that the Moslems in Beyrout had allowed him to talk in the public streets, and in his own way expound the Bible, because they thought him, in accordance with their superstitions, possessed of a Divining Spirit, and under the special protection of Allah. He talked with absolute plainness of the errors of the Oriental Churches and of Mohammedanism. 
In orthodox Damascus such discourses ended in a riot. In Beyrout, on the other hand, where he was widely known for his indiscriminate charity and real kindness of heart, he went about, usually without hindrance, his Bible in hand and would halt the first comer, native or foreigner, to urge him to repentance and belief. He established the British Mission Schools, begun, at the time of the massacres in 1860, by his sister-in-law, Mrs. Bowen Thompson, a woman of much excellence. Mrs. Mott and her husband had come to Syria later to take up Mrs. Thompson's work. Naturally Captain Burton did not enjoy the presence of a halfdemented Englishman, arousing fanaticism and breaking the laws almost within sight of the British Consulate, and Mr. Mott's visits to Damascus were cut short. $\mathrm{He}$ showed later a very unchristian vindictiveness towards the Consul.

Isabel Burton sympathised with the Shazlis, an important Moslem sect, and persuaded 
her husband to extend his consular protection to them, as she imagined that they were on the point of conversion to Rome. This annoyed the Wali, who had a very real dread of the British Consul's power and influence. Burton's position was shaken by the protection given to these people and by the just reprimand to Mr. Mentor Mott and to his officious and injudicious wife; together with a dispute with the Druzes, who had ill-treated some English missionaries. Constant complaints were sent by, and through, his enemies to the Foreign Office; and although his letters of defence, with their keen and pitiless logic, compared well with the illiterate accusations; the combination of commercial missionary and Jewish usurer was too strong, and one unhappy day, when the Consul and his great friend, Tyrwhitt Drake, were setting off for a desert ride, a tattered peasant boy handed a note to Burton that came like a bolt from the blue. It was from Kirby Beard, of Bey- 
rout announcing that by the direction of the Foreign Office he had arrived and taken over the Damascus Consulate, vice Burton recalled.

This peculiarly graceful way of announcing the change was the work of the ConsulGeneral at Beyrout, one Eldridge, a man of mediocre ability, who was bitterly jealous of the British Consul at Damascus, both because he was a gentleman and because he was a famous man. The blow fell heavily on Burton, but he never showed the bruise. For two years he had worked hard and had regained for Britain her lost prestige in Syria. At a moment's notice he was recalled because the Foreign Minister was a weak man, unable to withstand the lies of the incensed Jews and the hypocritical missionaries of the British Syrian Mission.

In spite of all, the man of fifty had as brave a heart as the boy of twenty boasted. A smile and a sneer alone marked the crisis, and he galloped on to Beyrout to embark 
for England, sending a message to his wife: "I am superseded; pay, pack, and follow at convenience."

The feeling of distressed amazement at Burton's recall was widespread, not only in Damascus, but throughout the wide confines of his Consulate and among all classes.

Mrs. Burton made a triumphant progress to the sea, when she had paid, and packed, and was ready to follow.

Not long after Captain Burton's departure his vindication was complete. The miserable Wali was degraded and all the reforms urged by Burton were carried out; a pity the British Syrian missionaries could not have been reformed at the same time. They needed it. 


\section{XII}

\section{HIS CONSULATE AT TRIESTE}





\section{XII}

HIS CONSULATE AT TRIESTE

W ${ }^{\text {HEN }}$ Mrs. Burton arrived in England she found Captain Burton sunk in the slough of despond, living alone in lodgings, wrapped in a mantle of gloomy dignity and taking no steps to put himself right with the Foreign Office; while he accepted the situation with what philosophy he might. Without a moment's delay this indomitable woman at once began a campaign, that never ceased until her own death, to rehabilitate her husband's character, so unjustly attacked. She stirred him up to reply to his detractors, to trace the source of the ridiculous lies told about him and to 
claim justice. Her letters to Lord Granville, the then Foreign Minister, to Sir Henry Elliott, the ambassador to Turkey, to Lord Derby, and others, have been called " marvels of special pleading," but they were of no immediate avail.

The two years at Damascus were the happiest in the life of the traveller and his wife. Even after the shock of recall had been diminished by time the ache of regret remained, and the longing for the tinkle of the camel bells in the long, light desert nights was always with them. After Mrs. Burton's return she besieged the Foreign Office, and at last compelled Lord Granville to hear her.

She insisted upon having the true reasons for Burton's recall, and answered them point by point-from the absurd complaints of the fanatical Motts to the lying charges of the Jewish usurers. For three months this conflict between the Foreign Office and the Burtons went on, and a Blue Book was finally issued on the subject. 
In January, 1872, the Burtons achieved a partial victory: the Foreign Office people showed a delayed sense of shame at their precipitate action, as was evidenced by the fact that Burton was offered the post of Consul at Pará, an offer which he indignantly refused. Here matters rested for a time.

The aggrieved pair paid many pleasant visits, and enjoyed seeing their friends, who rallied about them in great force; there was a general feeling about that the Government had treated Burton shabbily, and there was an evident disposition to resent the attitude of the Foreign Office.

In June, 1872, a cheerful diversion came for Burton in the form of a journey to Iceland, taken at the request of a certain financier named Lock, who was interested in the rich sulphur mines at Myvatn in the northern part of the country. Burton made a long and exhaustive report upon these mines and enjoyed his unexpected holiday. The usual book followed later on, "Ultima 
Thule; or, a Summer in Iceland," 1875. It was fortunate that Mrs. Burton did not accompany her husband, for during his absence her mother's long illness ended fatally without long notice: a great loss to Isabel. Shortly before Burton's return, about ten months after his undeserved recall from Damascus, Mrs. Burton received a letter from Lord Granville asking if her husband would accept the Consulate at Trieste, vacant on the death of Charles Lever, the writer, and paying about $£ 700$ a year. It was an unpleasant change after Damascus, but might well serve as a stepping-stone to something better. According to Isabel Burton's biographer, she was praying by her mother's coffin when the letter arrived, and she apparently regarded the letter as a direct answer to her prayers. She at once communicated with her husband and obtained his consent, then wrote to Lord Granville that he was willing to take the Consulate.

To offer a man with the fame of Burton 
a small dull Consulate like Trieste after his great services was no less than an insult; but Burton showed his pluck by accepting it without complaint, hoping that it might prove a stepping-stone to the Eastern Embassy he longed for but never obtained. Had Burton been an American he would have had the English mission, or later would have been Governor-General of the Philippines. Being an Englishman, he took what he could get and was as thankful as his sardonic humour would allow. The greatest Orientalist of his age became Consul at Trieste, where Lingua Franca and bastard German were the tongues understanded of the people!

Trieste, beautiful from the Adriatic as one comes into the harbour, is in reality a whited sepulchre. The climate is detestable, varying from arid heat in summer to a succession of continual gales in winter. Added to this is bad drainage and no system of sanitation. The eighteen years spent here by Burton 
ruined his health and undermined his constitution, so severely tried in early years. Fortunately, as at Santos, there was a ViceConsul who was ready to take the burden of routine work off his chief's shoulders.

Burton was ever fortunate in his assistants, with the unfortunate exception of Speke, whose disloyalty had so hurt him. Trieste, in spite of its drawbacks of Bora and Contraste, will remain associated with the name of Burton as the place where he made his great translation of the "Arabian Nights"the "Alf Laylah wa Laylah" dear to the Arabs.

Burton returned from the sulphur mines in Iceland in September, 1872, and in October started for Trieste by sea, leaving Isabel to do the usual paying, packing, and following. He never travelled by land when he could help it, as the salt air made him a giant refreshed.

Isabel Burton left England in November and travelled leisurely by way of Cologne, 
Würzburg, and Innsbruck to Venice. Here she wired her husband at Trieste, and then thoroughly enjoyed her first day's wanderings in a gondola. In the evening she went to call on the British Consul, Sir William Perry, who was a kindly old gentleman but very deaf. He muttered something about Captain Burton. Mrs. Burton said, "Oh, he is at Trieste." "No," said the Consul, "he has just left me. You had better come with me in my gondola; I am going to the Morocco now, a ship that will sail for Trieste." Mrs. Burton was much puzzled, but went with the old man. When she got aboard the ship the first person she saw was her husband, sitting quietly writing at the cabin table. "Halloa," said he, "what the devil are you doing here?" "Halloa," said she, "what are you doing here?" An amusing tale grew out of this which Isabel Burton relates thus: that the Burtons had been wandering separately all over Europe, amusing themselves, without knowing where each other was; that 
they had met quite by accident in Venice, shaking hands with each other like a pair of brothers who had met but yesterday, and then walking off to their hotel sat down to their writing as if nothing was the matter.

In addition to this the Burtons had been wiring and writing to each other at Trieste, to the amazement of the good old ViceConsul, Mr. Brock, who wondered what sort of people he was to meet.

At length they arrived at Trieste, after some delay at Venice, on December 6, 1872 , and it was amusingly but untruthfully reported that the new Consul and Mrs. Burton had taken up their abode at the Hôtel de la Ville, "he walking along with his gamecock under his arm, and she with her bull terrier."

When Isabel's relation, Lord Arundell of Wardour, knew that she was to live in Austria, he had authorised her to assume a title of the Holy Roman Empire that had 
been in the Arundell family for generations, and her cards were printed:

"Mrs. Richard Burton, nee Countess Isabel Arundell of Wardour."

This, of course, made the Burtons welcome at the Austrian Court, and right well did Isabel Burton bear her dignity of "Frau Gräfin."

For the first six months the Burtons lived at the hotel while they were looking for a house. The chief family, the local Rothschilds, was that of Baron Morpurgo, the director of the Austrian Lloyds, who was very attentive to the Burtons, and did much to make their dreary place of exile endurable.

The first public appearance of the new Consul and his wife was made at the marriage of Arthur Sassoon. They were always most popular in the curiously mixed society of Trieste, both with the Irridentist Italians and with the Austrians. In accordance with 
his usual custom, Burton at once commenced to look for a sanatarium in the hills where he might go for change of air and for rest. He soon picked out the Slav village of Opçina twelve hundred feet above Trieste, where the air was keen and bracing, and personally conducted parties were unknown. There the Burtons hired rooms by the year at the inn. After the first six months Mrs. Burton secured in Trieste a flat of six rooms on an upper floor of a tall block of buildings close to the sea. The rooms were furnished as to half with all the luxury of the East, and as to the other half with the plainness of a Western soldier. They were charmingly described in the World in 1877, under the heading of "The Celebrity at Home: Captain R. F. Burton at Trieste," by Alfred Bates Richards. The close of his article deserves to be quoted for its biting summing up of the situation, in speaking of Burton's exile:

"For years he has thought, studied, and written, and in all the four quarters of the 
globe has been a credit to his country. For years he has braved hunger, thirst, heat and cold, wild beasts, savage tribes; has fought and suffered, carrying his life in his hand. ... But like many of the greatest heroes that have ever lived, his country will deny him his meed of success while he lives, and erect marble statues and write odes to his memory when he can no longer see and hear themwhen God, who knows all, will be his reward."

The eighteen years at Trieste was the longest time the Burtons ever spent in one place, even when their frequent absences on "long leave" are considered. A typical day in their flat (which began with six rooms and ended with twenty-seven), where they lived for ten years, from 1872 to 1882, was as follows :-

The Consul and his wife rose about 4.30 or 5 a.m., made a simple breakfast of fruit and tea, and studied or wrote until noon. Then they went to the fencing school and 
afterwards swam or walked for two hours. Followed a short visit to the Consulate, and a dinner at the hotel with a party of friends. After the day together they both enjoyed the contact with other minds in the evening.

Burton lost no time in exploring the province, and his discoveries in Istria made somewhat of a stir.

Venice proved the saving grace. Whenever the crude harshness of the glowing white bastard-Italian town of Trieste grew too trying the Burtons would quietly go over to Venice, where the soothing charm of that nurse of tired spirits restored their mental poise.

That physicians fail to send their nervously exhausted patients to the healing quiet of the mother city of the Adriatic is a thing to wonder at.

Here, when Burton was tired, he never failed to find refreshment and rest for both body and soul, and here, more than elsewhere, did his laugh resemble that music of 


\section{HIS CONSULATE AT TRIESTE 201}

a pebble on a frozen lake his wife so often speaks of.

In 1873 the exhibition at Vienna claimed the Consul and his wife. The Countess Isabel was warmly received at Court, as the name of Arundell of Wardour was inscribed on the official lists of the Holy Roman Empire. Burton attended as an officer of the English Army, and they both enjoyed the experience but grumbled at the extortionate hotel bills-£160 for the three weeks they were there.

After 1872 their travels were frequent and fanciful and free. Before the exhibition a pilgrimage to Loretto had interested them, followed by a visit to Rome and Florence, where they saw much of Ouida (unappreciated for so long but now coming into her kingdom), who was an old friend. In December, 1874, Isabel Burton went to London to see publishers and attend to business matters, and in the following May, Burton joined her in England. In the course of the summer the 
famous portrait of Burton by Sir Frederic Leighton (afterwards Lord Leighton) was painted. It now hangs in the National Gallery. As usual, Burton became a social lion, and established his "Divans," where men dropped in after the opera or ball for a smoke and chat.

During this visit Burton met Gladstone and many other famous men, while he and Isabel both visited Professor Jowett at Oxford, and managed to include many house parties in their movements.

Isabel now tried hard to have her husband made a K.C.B., and have him transferred to Teheran. Although she could not persuade the Foreign Office people, the papers took up Burton's cause and called him the "neglected Englishman." For some reason several London papers were always hostile to Burton, and even now refuse the hospitality of their columns to a rare praise of the great traveller.

When he had had enough of London, 


\section{HIS CONSULATE AT TRIESTE 203}

Burton started on another voyage to Iceland, while his wife paid numerous visits to her friends. After his return Burton hurried off to Vichy to do a cure, and then rejoined his wife in London, where they mixed a great deal in society, and met many most interesting people. Mrs. Burton's book, "The Inner Life of Syria," was a great success, and she enjoyed her little triumph.

Early in December Burton decided to take his wife for a hurried journey to India, as he had still six months' leave. They stopped for a day or so at Boulogne, and then hurried on to Turin, Milan, Venice, and Trieste. They stopped at Trieste only eight days, and sailed on the Austrian Lloyd boat Calypso, for Port Said, Suez, and Jeddah. They enjoyed the voyage and especially the eight days spent at Jeddah at the British Consulate.

Long gallops in the desert reminded them of the lost delights of Damascus, and Isabel longed to push on to Meccah, but time and safety forbade. 
The fortnight's voyage to Bombay on the Calypso was miserable, for eight hundred pilgrims had been embarked at Jeddah, and their sufferings in overcrowded quarters were too awful for words. Grateful indeed were the Burtons on February 2, 1876, to land at Bombay safe and sound.

Some of Burton's old friends gave him a hearty welcome, and he and his wife enjoyed a three weeks' stay. From Bombay they made a tour including Poonah, Hyderabad, Golconda, and Goa, returning by the Austrian Lloyd boat Minerva at the end of April, and reaching the dreary town on the Adriatic on June 18, 1876. Burton's friendship with F. F. Arbuthnot, whom he met again in Bombay, was a pleasant but unimportant incident in his life, undeserving of the prominence given it by Wright. It was on this journey that Burton evolved his idea of having the Indian native princes sit in the House of Lords. 


\section{XIII}

HIS LESSER TRAVELS 



\section{XIII}

HIS LESSER TRAVELS

$A$ FTER the Indian tour husband and wife A enjoyed a prolonged period of rest at Trieste. They spent the summer chiefly at Opçina, with frequent visits to Trieste, for they both enjoyed swimming. At this time Burton took much pleasure in classifying his books, which now consisted of a collection of nearly eight thousand volumes. Any one of importance who passed through Trieste came of necessity to the Consul of world-wide fame. Indeed, it is no exaggeration to say that the Consul at Trieste was more of a personage in his way than the Ambassador at Vienna.

During this summer at Gorizia Isabel 
Burton had an audience of the Comte de Chambord (de jure Henri V. of France), whom she had known at Venice in earlier days. She was always a loyal Legitimist in French politics.

About this time Burton resolved to make an expedition to Midian in search of gold. He had heard of gems and of extensive mines, and resolved to make an expedition with a view to exploring the auriferous possibilities of the land. He easily obtained leave from the Foreign Office to go to Cairo, where Ismail, who was then Khedive, warmly welcomed his proposal and gave it his official sanction. This first short expedition lasted from March 31 to April 21, 1877, and was successful. Midian proved to be a rich country in both gold, silver, and iron, and Ismail Pasha was delighted with the report of the explorers. The hot weather made it necessary to postpone the second and longer expedition, and Burton returned to Trieste for the summer. He waited impatiently for the 
cooler days of autumn, and in October started again for the land of Jethro. Six weeks at Cairo sufficed for preparation, and the expedition started off gaily.

Two books followed in due course-the "Gold Mines of Midian," 1878, and "The Land of Midian Revisited," 1879.

It was a favourite joke with the friends of the Consul at this time to call him Duke of Midian, and wild tales of his expected riches were circulated.

The Khedive was much pleased with the success of Burton's journey and the richness of the specimens brought back. If Ismail had not abdicated when he did, a third expedition to Midian would certainly have taken place, but the weak and cowardly Tewfik, who succeeded his father, took no interest in the plan. Isabel Burton met her husband at Suez on his return from the second expedition to Midian, and went on with him to Cairo, where they were both lavishly entertained at Court and by unofficial people. An exhibition 
of the specimens brought by Burton was opened by Ismail Pasha, and drew great crowds.

From Cairo the Burtons went back to Trieste and Opçina for a brief rest before returning to London.

One of the Burtons' great friends was the famous General Gordon-"Chinese Gordon" -a man whose fate was similar to Burton's: both abandoned by their country; one, practically, to die like a dog in the desert, the other, theoretically, to eat his heart out in a third-rate seaport. After Gordon became Governor-General of the Soudan he wrote Burton :-

"You and I are the only two men fit to govern the Soudan; if one dies, the other will be left. I will keep the Soudan, you take Darfur; and I will give you $£ 5,000$ a year if you will throw up Trieste."

The Consul replied :-

"You and I are too much alike. I could not serve under you, nor you under me. I do 
not look upon the Soudan as a lasting thing. I have nothing to depend upon but my salary, and I have a wife and you have not." *

The Burtons reached London in July, 1878, having taken twenty-one days from Trieste to Liverpool in a comfortable Cunarder. During this voyage Burton had a touch of the gout that afterwards killed him. At this time the weary giant began to reap the reward of his long labours socially, if in no other way. A pleasant visit to Dublin made him the lion of the hour in Ireland, where he lectured several times and delivered a most erudite discourse on the Ogham Runes, the language of ancient Hibernia. A succession of visits to country houses followed a long list of dinners and receptions in London, where Burton was glad to escape to his pet haunt, the library of the Athenæum Club, where, Mr. Tedder the secretary states, he was always glad to chat with his friends, although he did not indulge in indiscriminate gossip. * Lady Burton's "Life," vol. ii. p. 43. 
The Haji particularly enjoyed a visit to Lord Salisbury at Hatfield, where Beaconsfield was a member of the house party. During this stay in London Burton delivered several lectures and renewed a delightful acquaintance with Sir Henry Irving. At this time Burton wrote a series of clever letters to the papers as Mirza Ali in London, describing to his brother Mirza Hasan in Shiraz the sights of the time. This idea was afterwards copied by Kipling, but without acknowledgment. Isabel Burton now published another book, " A. E. I." (Arabia, Egypt, India), which met with some success. When the Consul's leave had expired he went off to Trieste, leaving Isabel, as usual, to follow. She had an unfortunate and painful fall on the staircase of her hotel in Paris, but insisted upon going on to join her husband without delay at Trieste. This unwise journey after a severe shock and strain injured her health permanently, and in time she became a semi-invalid. During the summer, which they spent chiefly 
at Opçina, Isabel Burton grew better, after several "cures" had been tried, and in the autumn went for a short stay in her beloved Venice.

In December, 1879, Burton went off to Egypt again, to try to induce the Khedivial Government to reopen the Midian affair, but to no avail. During his absence Mrs. Burton grew worse again, and was ordered to London by a peremptory wire from her husband. She was under several celebrated physicians in London, but seems to have received but little benefit from their care.

Before she rejoined her husband at Trieste Isabel made her usual effort to get him a K.C.B., and asked for his promotion to Morocco. Unfortunately this was the exact moment when Lord Beaconsfield's last Ministry went out, and Lord Granville, who had made such a muddle of the Damascus matter, succeeded Lord Salisbury at the Foreign Office. Mrs. Burton received kind 
letters from Lady Salisbury and others, but achieved no practical results.

When she reached Trieste she found her husband ill from the combined effects of gout and a blow on the head received from a robber in the streets of Alexandria. With her usual promptness she bundled him off to their sanatarium at Opçina, and soon nursed him back to health, forgetful of her own condition.

During the summer of 1880 they went to see the Passion Play at Ober-Ammergau, and in 1881 Burton wrote a very powerful account of the tragedy, "A Glance at the Passion Play."

From 1880 to 1884 Burton published his wonderful translation of the "Lusiads" of Camoëns in several volumes. He had studied and lived with his favourite author for so long that he was thoroughly competent to render his verse in the English tongue. His translation at once and for ever displaced, and replaced, all other renderings, and made his 
fame secure. He dedicated the books to Swinburne, and that the great poet appreciated the tribute of the great traveller, is shown by his letter of November 7, 1884, to Burton, in which he says: "Your dedication makes me very proud." *

Gerald Massey on seeing the translation wrote some verses to Burton beginning

"Englished by Richard Burton. And well done, As it was well worth doing."

During 1880 Burton published his long poem "The Kasîdah," which had been written in 1854. Considered as poetry, it is both too long and too strong; Burton's verse has been called forced, but there is real power in this poem. It seems to have enraged the latest of Burton's biographers, Wright, who devotes more than a couple of pages in his second volume (pp. 20-22) to abusing it. However, only a poet could appreciate "The Kasîdah," and only a * Lady Burton's "Life," vol. ii. p. 183. 


\section{THE REAL SIR RICHARD BURTON}

scholar is capable of criticising what is too abtruse for ordinary mortals.

Another journey was in store for Burton, and after a long rest at Trieste he, in December, 1881, in company with his friend, V. Lovett Cameron, went out to the Gold Coast, at the request of Mr. James Irvine, to report upon some important concessions recently acquired by him upon the Ancobra river.

Burton met Cameron at Madeira, and the two friends leisurely travelled on to Axim by the s.s. Senegal, stopping at Bathurst and Freetown and reaching their journey's end late in January. Both husband and wife seem to have felt this parting more than usual, as they realised they were growing older. During Burton's absence all the ill effects of her fall in Paris seemed to concentrate in Isabel, and she suffered much pain. When she went in April to England to meet her husband, who was expected in May, she was strongly advised to consent to an operation 
that might have cured her, but she refused, as she did not wish to be laid up when her husband returned. Her devotion to him was so intense that she grudged every moment spent away from him.

Meanwhile, on the Gold Coast, while Cameron was surveying and making maps, Burton was studying the country minutely and conscientiously, as he did everything. $\mathrm{He}$ found that the Wasa country was very rich in gold and that there were signs of precious stones in addition. "To the Gold Coast for Gold," 1883, was the book that followed on this expedition.

His age, however, was telling even upon his iron constitution, and a severe attack of fever and ague showed him that he could no longer play tricks with his health. Acting on the urgent advice of Cameron, he took the next steamer to Madeira, where he waited for his friend to join him, while resting and recovering from his constant immersion in disused gold-pits, half-full of stagnant water. 
In May husband and wife met again at Liverpool, where there was a big dinner given to the two African travellers. The Burtons then went on to London for the season, where they were entertained largely and enjoyed seeing their friends. They reached Trieste in August, and were glad to rest for awhile.

In September Isabel Burton went to Marienbad for the baths, which did her a certain amount of good. In October of this year (1882) the Foreign Office wired Burton to go to Ghazzeh, in Syria, in search of his old friend Palmer, who had mysteriously disappeared, and who, it was afterwards discovered, had been treacherously murdered in the desert. This was the great traveller's last adventure, and, appropriately enough, it was in the East he loved. When Burton landed he found that Sir Charles Warren was scouring the desert, and was able to give him invaluable aid from his knowledge of the country and its dialects. Within two 
months he was back at Trieste. He realised that at last his travels were over. Burton had been writing all his life, but he now applied himself with renewed vigour to his literary work. His books are full of interest, the statement of his latest biographer, Wright, to the contrary, notwithstanding. They appeal to the scholar rather than to the reader of the Family Herald; but hold the reader's attention throughout. 



\section{XIV}

\section{HIS DEATH}





\section{XIV}

\section{HIS DEATH}

$A$ FTER the last adventurous dash across A the sea, life was quiet and peaceful at Trieste-or rather away from Trieste, for at length the Foreign Office began to recognise Burton's claim to unlimited leave.

Gone for ever now were the old wild days, and it was a very weary old man who worked away at his literary task. A beautiful palazzo a little outside of Trieste replaced the flat in the tall building, and it is cheering to reflect that the last years of the Haji were spent in luxury. The sun of prosperity, whose beams had been so intermittent during his long life, shone strong and bright during the last five years. 


\section{THE REAL SIR RICHARD BURTON}

Out of his great translation of "The Arabian Nights" he made some $£ 12,000$. This sum he spent so royally that after his death there was but a trifle left, which his widow put in the poor-box. Burton had a theory that every man had a metal that influenced him. His was silver, and after he had made some money all his objects in daily use were silver, where silver could be applied.

In January, 1885, Burton was so ill that he was tempted to resign from the consular service, but held on for two reasons, hoping that he might get Moroceo, and knowing that his full pension of $£ 300$ a year would be earned by March, 1891, but the climate of Trieste had done too well its deadly work.

In 1886 husband and wife celebrated their silver wedding at Gibraltar, and as an appropriate gift. a telegram addressed to "Sir Richard Burton" was handed to the Consul. He hesitated about opening it at first, but at his wife's request did so. It proved to be from Lord Salisbury, saying in the kindest way that 
Queen Victoria had made Burton a K.C.M.G., * in reward for his services.

So after many weary years, a short time before his death, Richard Burton came into his own, despite the curs that still snarled at his heels. Had Lord Salisbury's first Ministry lasted longer, Burton would probably have had Morocco, but unfortunately the Liberals came in, and he was no favourite with the "Little Englanders."

One of the Ministers wrote Lady Burton at the time, "We don't want to annex Morocco, and we know that you two would be Emperor and Empress in about six months."

In January, 1887, Sir Richard and Lady Burton enjoyed a stay on the Riviera, where they met the then Prince of Wales, and experienced the famous earthquake of that year.

At this time Sir Richard became more or less of a chronic invalid, and in future Lady Burton had always a resident physician with her.

× Knight Commander of St. Michael and St. George. 
The last public appearance of Sir Richard Burton was at the Jubilee Dinner at Trieste in 1887 , where he made a charmingly witty and pathetic speech in proposing Queen Victoria's health.

Short journeys to England, Switzerland, and Malta followed-short because the rugged frame, upright for so long, was bending now.

In Switzerland about this time, Sir Richard gave Lady Burton the following important signed paper: "In the event of my death I bequeath especially to my wife, Isabel Burton, every book, paper, or manuscript, to be overhauled and examined by her only, and to be dealt with entirely at her own discretion and in the manner she thinks best, having been my sole helper for thirty years." *

The shades of the evening of life were fast closing in about the old hero. But a short time remained to him, and some idea of his coming end must have been present to his

* "The Romance of Isabel, Lady Burton," vol. ii. p. 696. 
mind, for in the early eighties he worked, as few have worked since Sir Walter Scott, over his great task, the translation of the "Alf Laylah wa Laylah" of the Arab, "The Thousand Nights and a Night" of the scholar, "The Arabian Nights" of the man in the street.

This was Burton's greatest labour: this showed him as a great translator, as a man of almost superhuman knowledge-knowledge of Arabic and Persian, knowledge of customs, tribal rites, and Eastern ways, that leave him without a rival.

His edition of "The Arabian Nights" is far above all others, be they Scott's, Weil's, Payne's, or Lane's. The charge made by Wright in his so-called Life of Burton, that the Haji plagiarised from Payne-a charge which he endeavours to fortify by extracts in parallel columns from Burton's and Payne's editions of the "Nights"-is ridiculous. Burton had no need to steal Payne's German inspired thunder. That there is some re- 
semblance between certain long extracts is undeniable, a necessary resemblance in Englishing the text. Indeed, Burton once said that Payne's choice of words was so good, he had made it hard for further translation;* but if Burton owes anything to Payne through plagiarism, why is it that Payne's "Nights" - which are all Payne's-have never ranked either among scholars, or generally, with Burton's? Why is Burton's edition the definitive edition? Burton's whole life, his long list of translations, forbids the belief that he owed more to Payne than to any Orientalist.

While on this subject it may be well to allude to the burning by Lady Burton of her husband's translation of "The Scented Garden." Much nonsense has been written

* "A good translation, especially in prose, must go more or less on similar lines. There are some very similar expressions in the 'Nights' that might lead to the highly improbable notion that Lane or Weil had copied from each other" (Letter from Mr. W. F. Kirby -the authority on the "Nights"- to the author). 
upon this incident. The fact was simple. Lady Burton had been made his literary executor by Sir Richard. In the exercise of her right and discretion, finding that the manuscript was unfinished and unpolished, and not approving of the subject matter, she burned it, having due regard to her husband's literary reputation.

Her own account of this incident is to be preferred to the harrowing and romantic scenes read into the holocaust by Burton's biographers and her's.

That Lady Burton chose, while her husband lay dying, or possibly dead, to have the last rites of her own Church administered to him, is not a matter for the public. That certain biographers should have torn aside the veil of privacy from the death-bed of the great explorer is to be regretted, but not to be commented on.

As he would have preferred, the old traveller died in harness. Suddenly and with no preliminary flickering, the light went out. 
Very early in the morning of a dull October day in 1890 Sir Richard Burton went on his last long expedition, to explore lands new even to him. Who can doubt that he faced the crossing of the Styx with the same coolness and courage he had ever shown! or that his hail of Charon bore the right accent!

The man was dead at Trieste, but the name of the man was alive, and will live on in the hearts of the British race, for Richard Burton was a Briton of the Eimpire.

Lady Burton's desolation may be imagined. It is better left to the imagination than impertinently analysed and dissected in the peering, prying, modern way.

Her only ambition was to pay, pack, and follow for the last time. A public subscription built the white stone Arab tent at Mortlake where the Burtons rest from their long and weary labours. A huge work in two large volumes remains as a proof-if 
that were needed-of the love of Isabel Burton for her husband.* She did not long enjoy the pension of $£ 150$ a year granted her by Queen Victoria from the Civil List.

When she had paid and packed, she gladly-very gladly-followed; and on March 22, 1896, the soul of Isabel Arundell went out to meet the spirit of her lover of long ago.

The old romance grows sweeter as time goes on. Boulogne, Damascus, Trieste-these were the names engraved on the heart of the devoted woman who fought so loyally and bravely for the man she loved.

She was a good woman.

* "The Life of Captain Sir Richard F. Burton, K.C.M.G., F.R.G.S.," by his wife, Isabel Burton. London: Chapman \& Hall, 1893. 



\section{XV}

\section{ITE. MISSA EST}





\section{$\mathrm{XV}$}

ITE. MISSA EST

T $\mathrm{N}$ his Arab tent of stone, under the camel 1 bells that he loved, down in the Catholic Cemetery at Mortlake, his devoted wife by his side, rests one of the greatest Englishmen of his time. Drake, Raleigh, Frobisher, Livingstone, Stanley-these are the giants with whom he ranks.

Rugged and great in body, great and rugged in mind, Richard Francis Burton left an impress on his century. "Honour, not honours," was his motto, and this motto he faithfully carried out in his life.

He worked hard, he rested hard. In himself he combined the passion of the Kelt, the doggedness of the Anglo-Saxon. 
It is hard to define a great man, in these days when so many are notorious.

If a great man be a man who towers above his fellows by sheer force of character, by deeds of derring-do, by unfaltering service, unselfish always to his country by a scathing scorn of dishonesty, Richard Burton was a great man. His fame grows steadily year by year, and the wonder why he was not given a place in Westminster Abbey grows also, for as time goes on he is seen to overtop his contemporaries more and more.

With all his faults, Richard Burton was one of those rare spirits who appear from century to century, and, having done their work for England, disappear for the moment, until their country's need brings them back in another incarnation.

In his biographers Burton has been unfortunate. Lady Burton's work was a tribute of such romantic devotion as is rarely seen, but while the world is glad to know that her husband was a demi-god to her, it wants 
to know the man better from the impartial point of view of an outsider.

No one who reads all the so-called "Lives" can help a feeling of distressed wonder at these squabbles in print over unimportant points of detail. Burton-who thought Imperially - would have brushed them aside with a reference to the gossip of the servants' hall. It takes a great man to write the life of a great man, and there are few such "Lives"! In spite of the differing accounts of his career, now over-flattering, now venomously friendly; he will be judged fairly by posterity-this most fascinating ancient among the moderns.

No study of his career, no time spent in reading his books, can fail to convince the seeker after knowledge that here was a wandering Knight of King Arthur's Court, a Lancelot in modern guise.

Great as an explorer, famous as an author, a renowned scholar and translator, an ethnological and anthropological authority, a 


\section{THE REAL SIR RICHARD BURTON}

linguist without a peer, Sir Richard Burton, Knight, a gentleman of Hertfordshire, takes his place-no mean one-in the Hall of Fame.

Finis. 
ABD-EL-KADIR, 75, 173

Abdullah Effendi el Hálabi, 173-4

Abruzzi, Duke of the, 113

"A.E.I.", 212

Anthropological Society's dinner to Burton, 150

"Arabian Nights, The," 17, 47, 85, 194, 224,227

Arbuthnot, F. F., 204

Arundell, H. R., father of Lady Burton, $60,102,119-22,128-33$ Lord, 146, 196

" Mrs., mother of Lady Bur ton, $60,102,119-22$, 128-30, 137, 192

BAATBEE, 180

Baroda, Burton's stay at; 41-4

Bayonet Exercise, Burton's book on, 58

Beaconsfield, Lord, 212

Beard, Kirby, 184-5

Beatson, General, 93-4, 96

Bird, Dr., 131

Bliss, Dr. Daniel, 164

Bombay, Burton's voyage to, 204

"Book of the Sword," 30

Boulogne, Burton's first stay at, 57

Brock, Consul, 196

Buenos Ayres, Burton at, 161

Burckhardt, J. L., 67

Burton, Edward, 22 foll., 32, 39, 92

Burton, Hagar, 60

Burton, Lady, her "Life of Captain

Sir Richard F. Burton," 7, 9, 236;

her first meeting with Burton, 58;

her parentage, 60 ; her character,

62 ; notes from her journal, 80,97

her engagement, 101-3, 120; her anxiety during Burton's absence, 117-8; obstacles to their marriage, 119-24; their wedding, 128-33; her early married life, 137-8, 141, 145-50; her voyage to Santos, 153-6; her efforts in London, 162 ; her journey to Damascus, 171 , and life there 171-86; her defence of Burton, 18990; her journey to Trieste, 194-6 "Countess Isabel Arundell of Wardour," 196-7; her life at Trieste, 196-201; her journey to India, 203-4; failure of her health, 212; her labours for her husband's promotion, 213-4; her burning of "The Scented Garden," 228-9; the question of the last rites, 229 ; her death, 231

Burton, Lieut.-Col. J. N., father of Sir Richard, 22-30, 34, 39, 110

Burton, Mrs., mother of Sir Richard, 22-3, 91

Burton, Sir Richard, various "lives," 7-10, 236-7; his achievements, 15-7; his birth and boyhood, 17-35: his education on the Continent, 22-31; his Oxford days, 31-5; his army life in India, 39-54; his disguises, 46-7; his study of Mohammedanism, 50-3; his stay at Boulogne and meeting with Isabel Arundell, 58-63; his pil- grimage to Meccah, 63-81; his exploration of Harar, 82-8; his engagement to Isabel Arundell, 101-3; his exploration of the sources of the Nile, 103-14; obstacles to his marriage, 119-24; his visit to the Mormons, 124-7; his marriage, 128-33; his Consulate at Fernando Po, 13947 ; his mission to Dahomé, 147-8; his Consulate at Santos, 150, 156-60; his expedition to Paraguay, 160-1; his appointment to Damascus, 1623 ; his Consulatie there, 169-86; his trips to Iceland, 191-2, 194, 203; his Consulate at Trieste, 192-230; his journey to India, 203-4; his expedition to Midian, 208-10; his translation of Camoëns, 214; “The Kasîdah," 215-6; his expedition to the Gold Coast, 216-9; receives knighthood, 224-5; his bequests to Iuady Burton, 226-7; his "Arabian Nights", $227-8$; his death, 230 ; estimate of his greatness, 235-8

Cameron, V. Lovetw, 216

Camoëns, Burton's translation of, 214 Caroline, Queen, 24

Chambord, the Comte de, 208

Chand, Him, 43

"City of the Baints, The," 125

Clarendon, Lord, 106, 163, 169, 172

Constable, Sir Clifford, 127

DAFоMÉ, Burton's mission to the King of, 147

Damascus, Burton's Consulate at, 162-86

Dana, Lieutenant, 126

Delafosse, - , tutor to the Burtons, 26

Derby, Lord, 150, 163, 190

Drake, Tyrwhitt, 180-1, 184

Druses, the, 184

Du Pré, -, tutor to the Burtons, 28

Dublin, Burton's visit to, in 1878, 211

ELPHINSTONE, LORD, 104

"Explorations in the Highlands of Brazil," 157

Eldridge, Consul-General, 185

Ellenborough, Lady, 176-9

Elliott, Sir Henry, 190

"FarconRy in the Valley of the Indus," 46

Fernando Po, Burton's Consulate at, 139-47

"First Footsteps in East Africa," 85

GANNEAU, - , 180-1

Gerard, Liord, 146

Gladstone, W. E., 202

"Glance at the Passion Play, A," 214

"Goa and the Blue Mountains," 50

Gold Coast, Burton's expedition to the, 216-7

"Gold Mines of Midian," 209

Gordon, General, 210

"Gorilla Land," 145

Grant, J. A., 107, 112-3

Granville, Lord, 190, 192, 213

Grindlay, Captain, 65 


\section{Grindlay's, the fire at, 139}

HAMERTON, LIEUT.-COLONEL, 106

Hamid, Shaykh, 70, 72-3

Harar, Burton's exploration of, 82-8

Hearne, Rev. Dr., 131

Herne, Lieutenant, 83, 87-8

Hitchman, Francis, his "Life" of Burton, 7

Houghton, Lord, 138

Hughes, Thomas, 33

IoELAND, Burton's trips to, 191-2, 194, 203

"Inner Life of Syria, The," 179

"Iracema, or Honey Lips," 161

Irvine, James, 216

Irving, Sir Henry, 212

Ismail Pasha, 208-10

JEwISH money-lenders, Burton's trouble with, 176, 185

Jowett, Benjamin, 202

KARÁCHI, Burton's stay at, 44

Kars, Burton's plan for the relief of, 95

"Kastdah, The," 81, 215

Kipling, Rudyard, 47, 212

Kirby, W. F., 228

"LAand of Mrdian Revisited, The," 209

"Lands of the Cazembe, The," 161

Lane's "Arabian Nights," 227-8

Layard, Sir Henry, 145

Leighton, Lord, 174, 202

Lever, Charles, 192

MADINAH, AL, Burton at, 72

Massey, Gerald, 215

Maysinah, Song of, 73

Meccah, Burton's pilgrimage to, 63

Mezráb, Shaykh el, 176-8

Midian, Burton's expedition to, 208-10

Mijwal-el-Mezráb, Shaykh, 75

Milnes, Monckton(Loro Houghton), 101

Mirza Ali Abdullah of Bushiri, 46-7, 212

Mirza Daud, 47

"Mission to the King of Dahomé, A," 147

Missionaries, Burton's attitude towards, 163-5

Mohammedanism, Burton's study of, 50-3

Mormons, Burton's visit to the, 123-7

Morpurgo, Baron, 197

Mott, Mentor, 164, 182-4

Murchison, Sir Robert, 162

NAPIER, SIR CHARLES, 16

Niffon, Bishop, 182

Nile, Burton's exploration of the sources of the, 103

Nux, 68

Ober-Ammergau, the Passion Play at, 214

Oliphant, Laurence, 113

Ouida, 201

Outram, Sir James, 83

Oxford, Burton's career at, 31-5

PaLimer, E. H., 180-1, 218

Palmerston, Lord, 138

Pará, Burton offered Consulate at, 191
Paraguay, the battlefields of, $160-1$

Payne, John, 8, 227-8

Perry, Sir William, 195

"Pilgrimage to Meccah and $\mathrm{Al}$ Madinah," 69'

Portugal, Burton's visit to, 150-4

Post, Dr., 164

"Proverba Communia Syriaca," 179

RAGLAN, LORD, 39

Rá'shid Pasha, 173

Richards, Alfred Bates, 33, 198-9

Richards, Wilson and Baddeley, their "Life" of Burton, 7

Richmond, Burton's schooldays at, 26-7

Russell, Lord, 148-9

SALISBURY, LORD, 212, 224

Santos, Burton's Consulate at, 150-60

Sassoon, Arthur, 197

"Scented Garden, The," 228

"Scinde, or the Unhappy Valley," 44

Scott, Colonel Walter, 45, 48, 53

Scott, Sir Walter, 227

Shazlis, the, 183

Short, Rev. Thomas, 33

Sikh War, the, 49

Simpson, General, 93

"Sind Revisited," 44

Sorrento, Burton at, 29

Speke, H., 83, 87-8, 104, 149, 194

Stanley, H. M., 107, 113

Stanley, Lord (Lorá Derby), 150, 163, 190

Steinhäuser, Dr., 49, 61, 84, 104-14

Stisted, Lady, 22

Stisted, Miss, her "Life" of Burton, $7,48,63$

Stratford, Lord, 94-5

Stroyan, Lieutenant, 83, 87-8

Sufi-ism, Burton's study of, 51

Swinburne, A. C., 215

TADMOR, Burton's expedition to, 177-8

Tanganyika, Lake, discovered by Burton, 105, 109

Tedder, Mr., 211

Tewfik Pasha, 209

Thompson, Mrs. Bowen, 183

Thornton, Sir Edward, 155

"To the Gold Coast for Gold," 217

Tours, Burton's stay at, 22-5

Trieste, Burton's Consulate at, 192-230

"ULTIMA ThuLe," 191-2

" Unexplored Syria," 179

VENICE, Burton's visits to, 195, 200

Victoria Nyanza, Lake, discovered by Speke, 110

Vienna, the Exhibition at, 201

"WANDERINGS IN West AFrICA," 142

Warren, Sir Charles, 180-1, 218

Weil's "Arabian Nights," 227-8

Wilkins, W. H., his "Life" of Burton, 8

Wingfield, F., 93

Wiseman, Cardinal, 105, 129

Wolf, Robert T., 126

Wright, Thomas, his "Life" of Burton, 8, 21, 48, 63, 204, 215, 228

YOUNG, BRIGHAM, 125, 127

UNWIN BROTHERS, IIMITED, THE GRESHAM PRESS, WOKING AND LONDON. 

I b e oi 

